\title{
Distribution of planktonic biogenic carbonate organisms in the Southern Ocean south of Australia: a baseline for ocean acidification impact assessment
}

\author{
Thomas W. Trull ${ }^{1,2,3}$, Abraham Passmore ${ }^{1,2}$, Diana M. Davies ${ }^{1,2}$, Tim Smit ${ }^{4}$, Kate Berry ${ }^{1,2}$, and Bronte Tilbrook ${ }^{1,2}$ \\ ${ }^{1}$ Climate Science Centre, Oceans and Atmosphere, Commonwealth Scientific and Industrial Research Organisation, \\ Hobart, 7001, Australia \\ ${ }^{2}$ Antarctic Climate and Ecosystems Cooperative Research Centre, Hobart, 7001, Australia \\ ${ }^{3}$ Institute of Marine and Antarctic Studies, University of Tasmania, Hobart, 7001, Australia \\ ${ }^{4}$ Utrecht University, Faculty of Geosciences, Utrecht, 3508, the Netherlands
}

Correspondence: Thomas W. Trull (tom.trull@csiro.au)

Received: 1 June 2017 - Discussion started: 12 June 2017

Revised: 5 November 2017 - Accepted: 8 November 2017 - Published: 3 January 2018

\begin{abstract}
The Southern Ocean provides a vital service by absorbing about one-sixth of humankind's annual emissions of $\mathrm{CO}_{2}$. This comes with a cost - an increase in ocean acidity that is expected to have negative impacts on ocean ecosystems. The reduced ability of phytoplankton and zooplankton to precipitate carbonate shells is a clearly identified risk. The impact depends on the significance of these organisms in Southern Ocean ecosystems, but there is very little information on their abundance or distribution. To quantify their presence, we used coulometric measurement of particulate inorganic carbonate (PIC) on particles filtered from surface seawater into two size fractions: $50-1000 \mu \mathrm{m}$ to capture foraminifera (the most important biogenic carbonate-forming zooplankton) and 1-50 $\mu \mathrm{m}$ to capture coccolithophores (the most important biogenic carbonate-forming phytoplankton). Ancillary measurements of biogenic silica (BSi) and particulate organic carbon (POC) provided context, as estimates of the biomass of diatoms (the highest biomass phytoplankton in polar waters) and total microbial biomass, respectively. Results for nine transects from Australia to Antarctica in 2008-2015 showed low levels of PIC compared to Northern Hemisphere polar waters. Coccolithophores slightly exceeded the biomass of diatoms in subantarctic waters, but their abundance decreased more than 30-fold poleward, while diatom abundances increased, so that on a molar basis PIC was only $1 \%$ of BSi in Antarctic waters. This limited importance of coccolithophores in the Southern Ocean is further emphasized in terms of their
\end{abstract}

associated POC, representing less than $1 \%$ of total POC in Antarctic waters and less than $10 \%$ in subantarctic waters. NASA satellite ocean-colour-based PIC estimates were in reasonable agreement with the shipboard results in subantarctic waters but greatly overestimated PIC in Antarctic waters. Contrastingly, the NASA Ocean Biogeochemical Model (NOBM) shows coccolithophores as overly restricted to subtropical and northern subantarctic waters. The cause of the strong southward decrease in PIC abundance in the Southern Ocean is not yet clear. The poleward decrease in $\mathrm{pH}$ is small, and while calcite saturation decreases strongly southward, it remains well above saturation $(>2)$. Nitrate and phosphate variations would predict a poleward increase. Temperature and competition with diatoms for limiting iron appear likely to be important. While the future trajectory of coccolithophore distributions remains uncertain, their current low abundances suggest small impacts on overall Southern Ocean pelagic ecology.

\section{Introduction}

The production of carbonate minerals by planktonic organisms is an important and complex part of the global carbon cycle and climate system. On the one hand, carbonate precipitation raises the partial pressure of $\mathrm{CO}_{2}$ reducing the uptake of carbon dioxide from the atmosphere into the surface 
ocean; on the other hand, the high density and slow dissolution of these minerals promotes the sinking of associated organic carbon more deeply into the ocean interior, increasing sequestration (Boyd and Trull, 2007b; Buitenhuis et al., 2001; Klaas and Archer, 2002; Ridgwell et al., 2009; Salter et al., 2014). Carbonate production is expected to be reduced by ocean acidification from the uptake of anthropogenic $\mathrm{CO}_{2}$, with potentially large consequences for the global carbon cycle and ocean ecosystems (Orr et al., 2005; Pörtner et al., 2005).

The low temperature and moderate alkalinity of Southern Ocean waters make this region particularly susceptible to ocean acidification, to the extent that thresholds such as undersaturation of aragonite and calcite carbonate minerals will be crossed sooner than at lower latitudes (Cao and Caldeira, 2008; McNeil and Matear, 2008; Shadwick et al., 2013). Carbonate-forming organisms in the Southern Ocean include coccolithophores (the dominant carbonate-forming phytoplankton; e.g. Rost and Riebesell, 2004), foraminifera (the dominant carbonate-forming zooplankton; e.g. Moy et al., 2009; Schiebel, 2002) and pteropods (a larger carbonateforming zooplankton, which can be an important component of fish diets; e.g. Doubleday and Hopcroft, 2015; Roberts et al., 2014). However, the importance of carbonate-forming organisms relative to other taxa is unclear in the Southern Ocean (Gregg and Casey, 2007b; Holligan et al., 2010). Satellite reflectance observations, mainly calibrated against Northern Hemisphere particulate inorganic carbonate (PIC) results, suggest the presence of a Great Calcite Belt in subantarctic waters in the Southern Ocean and also show high apparent PIC values in Antarctic waters (Balch et al., 2016, 2011). Our surveys were designed in part to evaluate these assertions for waters south of Australia.

As a simple step towards quantifying the importance of planktonic biogenic carbonate-forming organisms in the Southern Ocean, we determined the concentrations of PIC for two size classes, representing coccolithophores $(1-50 \mu \mathrm{m}$, referred to as PIC01) and foraminifera $(50-1000 \mu \mathrm{m}$, referred to as PIC50), from surface water samples collected on nine transects between Australia and Antarctica. We provide ecological context for these observations based on the abundance of particulate organic carbon (POC) as a measure of total microbial biomass and biogenic silica (BSi), the other major phytoplankton biogenic mineral, as a measure of diatom biomass. This provides a baseline assessment of the importance of calcifying plankton in the Southern Ocean south of Australia, against which future levels can be compared.

In the discussion of our results, we interpret BSi as representative of diatoms, PIC50 as representative of foraminifera, and PIC01 as representative of coccolithophores, including a tendency to equate this with the distribution of the most cosmopolitan and best-studied coccolithophore, Emiliania huxleyi. These assumptions need considerable qualification. Most BSi is generated by diatoms $(\sim 90 \%)$, with only minor contributions from radiolaria and choanoflagellates in the upper ocean, making this approximation reasonably well supported (Hood et al., 2006). Similarly, but less certainly, foraminifera are a major biogenic carbonate source in the $50-1000 \mu \mathrm{m}$ size range, but pteropods, ostrocods and other organisms are also important (Schiebel, 2002). We do not discuss the PIC50 results in any detail because of this complexity; because controls on foraminifera distributions appear to involve a strongly differing biogeography of several co-dominant taxa, rather than dominance by a single species (Be and Tolderlund, 1971); because the numbers of these organisms collected by our procedures were small; and because assessing these issues is beyond the scope of this paper. Attributing all the PIC01 carbonate to coccolithophores relies on the assumption that fragments of larger organisms are not important. This seems reasonable given that the larger PIC50 fraction generally contained 10-fold lower PIC concentrations (as revealed in the "Results and discussion" section).

Our tendency to equate the PIC01 fraction with the abundance of Emiliania huxleyi is probably the weakest approximation. It is not actually central to our conclusions, except to the extent that we compare our PIC01 distributions to expectations based on models that use physiological results mainly derived from experiments with this species. That said, this is a poor approximation in subtropical waters, where the diversity of coccolithophores is large, but improves southward, where the diversity decreases (see Smith et al., 2017, for recent discussion), and many observations have found that Emiliania huxleyi was strongly dominant in subantarctic and Antarctic Southern Ocean populations, generally $>80 \%$ (Boeckel et al., 2006; Eynaud et al., 1999; Findlay and Giraudeau, 2000; Gravalosa et al., 2008; Mohan et al., 2008). Of course, Emiliania huxleyi itself comes in several strains even in the Southern Ocean, with differing physiology, including differing extents of calcification $\mathrm{Cu}-$ billos et al., 2007; Muller et al., 2015, 2017; Poulton et al., 2013, 2011). All these approximations are important to keep in mind in any generalization of our results. We also note that our technique does not distinguish between living and nonliving biomass and thus is more representative of the history of production than the extent of extant populations at the time of sampling.

\section{Methods}

Sections 2.1 and 2.2 present the sampling and analytical methods, respectively, used for the eight transits across the Southern Ocean since 2012. Section 2.3 details the different methods used during the earlier single transit in 2008 and assesses the comparability of those results to the later voyages. Section 2.4 details measurements of water column dissolved nutrients, inorganic carbon and alkalinity. Section 2.5 provides details of satellite remote-sensing data and the NASA Ocean Biogeochemical Model used for comparison to the ship results. 
Table 1. Sample collection. SIPEX-II: Sea Ice Physics and Ecosystem eXperiment 2012.

\begin{tabular}{|c|c|c|c|c|c|c|c|}
\hline No. & Voyage name & Leg & Dates & $\mathrm{PIC} 50^{\mathrm{c}}$ & $\mathrm{PIC} 1^{\mathrm{c}}$ & $\mathrm{POC} \& \mathrm{PON}^{\mathrm{c}}$ & $\mathrm{BSi}^{\mathrm{c}}$ \\
\hline VL1 & AA2008_V6 (SR3) & North & 28 Mar 2008-15 Apr 2008 & $57 / 0$ & $59 / 0$ & $59 / 0$ & $59 / 0$ \\
\hline VL2 & AA2012_V3 (I9) & South & 5 Jan 2012-20 Jan 2012a & $4 / 16$ & $4 / 16$ & $9 / 25$ & $7 / 22$ \\
\hline VL3 & AA2012_V3 (I9) & North & 20 Jan 2012-9 Feb 2012 & $62 / 0$ & $62 / 0$ & $59 / 0$ & $53 / 0$ \\
\hline VL4 & AA2012_VMS (SIPEX-II) & South & 13 Sep 2012-22 Sep 2012 & $0 / 20$ & $0 / 19$ & $0 / 24$ & $0 / 24$ \\
\hline VL5 & AA2012_VMS (SIPEX-II) & North & 11 Nov 2012-15 Nov 2012 & $0 / 24$ & $0 / 24$ & $0 / 27$ & $0 / 28$ \\
\hline VL6 & AL2013_R2 (l'Astrolabe) & South & 10 Jan 2013-15 Jan 2013 & $0 / 25$ & $0 / 25$ & $0 / 23$ & $0 / 25$ \\
\hline VL7 & AL2013_R2 (l'Astrolabe) & North & 25 Jan 2013-30 Jan 2013 & $0 / 27$ & $0 / 27$ & $0 / 26$ & $0 / 27$ \\
\hline VL8 & AA2014_V2 (Totten) & South & 5 Dec 2014-11 Dec 2014 & $0 / 36$ & $0 / 36$ & $0 / 32$ & $0 / 37$ \\
\hline VL9 & AA2014_V2 (Totten) & North & 22 Dec 2014-24 Jan 2015 b & $6 / 44$ & $6 / 44$ & $8 / 27$ & $8 / 39$ \\
\hline
\end{tabular}

a The 18-20 January 2012 east-to-west traverse from approximately $65^{\circ} \mathrm{S} 144^{\circ} \mathrm{E}$ to $65^{\circ} \mathrm{S} 113^{\circ} \mathrm{E}$ included in south leg; see Fig. 1 .

b The 22 December 2014-11 January 2015 west-to-east traverse from approximately $65^{\circ} \mathrm{S} 110^{\circ} \mathrm{E}$ to $65^{\circ} \mathrm{S} 140^{\circ} \mathrm{E}$ included in north leg; see Fig. 1 .

c Numbers of samples collected on station/underway.

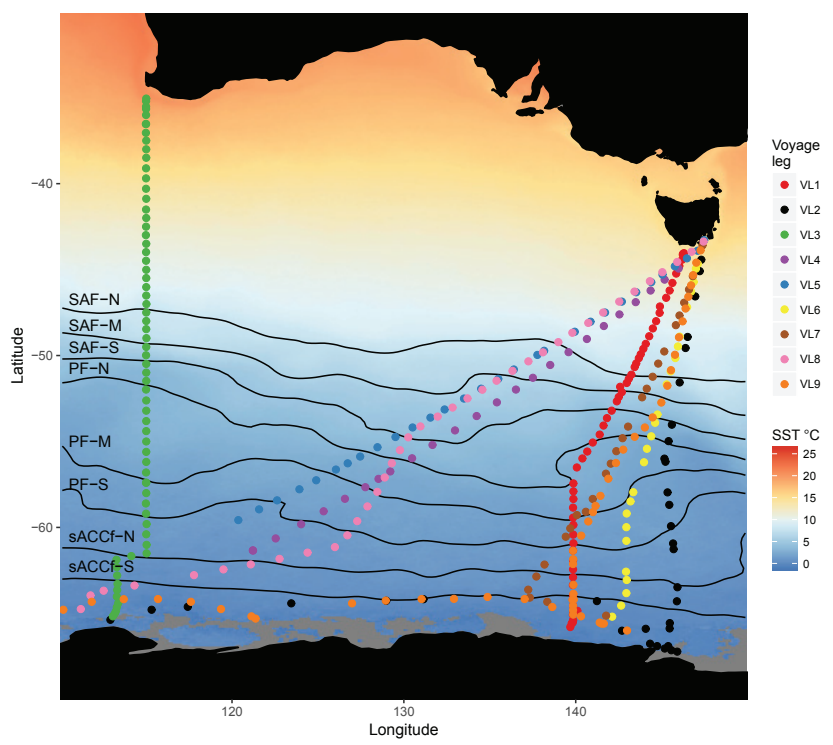

Figure 1. Map of sample sites (dots) relative to major Southern Ocean fronts (lines) and satellite SST (means for productive months, October-March, over the sample collection period 20082014). Front abbreviations: SAF - Subantartic Front; PF: Polar Front; sACCf: Southern Antarctic Circumpolar Current Front; N: north; M: middle; S: south.

\subsection{Voyages and sample collection procedures}

The locations of the voyages, divided into north and south legs, are shown in Fig. 1. Voyage and sample collection details are given in Table 1, where for ease of reference we have numbered the legs in chronological order and refer to them hereafter as VL1, VL2, etc. Samples were collected from the Australian icebreaker RV Aurora Australia for four voyages and from the French Antarctic resupply vessel l'Astrolabe for one voyage. All samples were collected from the ships' underway "clean" seawater supply lines with intakes at $\sim 4 \mathrm{~m}$ depth. These supply lines are separate from the engine intakes, have scheduled maintenance and cleaning, and are only turned on offshore (to avoid possible contamination from coastal waters). Samples were collected primarily while underway, except during VL1 and VL3, which were operated as World Ocean Circulation Experiment/Climate and Ocean Variability, Predictability and Change (WOCE/CLIVAR) hydrographic sections with full depth conductivity-temperature-depth (CTD) measurements, with samples collected on station.

For all voyages (except VL1, discussed in Sect. 2.3 below), separate water volumes were collected for the PIC, POC and $\mathrm{BSi}$ analyses. The POC samples also yielded particulate nitrogen results - referred to here as PON. The POC/PON and BSi samples were collected using a semi-automated system that rapidly $(\sim 1 \mathrm{~min})$ and precisely filled separate $1 \mathrm{~L}$ volumes for each analyte - thus, these samples are effectively point samples. In contrast, PIC samples were collected using the pressure of the underway seawater supply to achieve filtration of large volumes (tens to hundreds of litres) over $\sim 2 \mathrm{~h}$. Thus, these samples represent collections along $\sim 20$ nautical miles of the ship track (except when done at stations).

POC/PON samples were filtered through pre-combusted $13 \mathrm{~mm}$ diameter quartz filters $(0.8 \mu \mathrm{m}$ pore size, Sartorius catalogue no. FT-3-1109-013) that had been pre-loaded in clean (flow-bench) conditions in the laboratory into in-line polycarbonate filter holders (Sartorius no. 16514E). The filters were preserved by drying in their filter holders at $60^{\circ} \mathrm{C}$ for $48 \mathrm{~h}$ at sea and returned to the laboratory in clean dry boxes.

Biogenic silica samples were filtered through either $13 \mathrm{~mm}$ diameter nitrocellulose filters $(0.8 \mu \mathrm{m}$ pore size, Millipore catalogue no. AAWP01300) or $13 \mathrm{~mm}$ diameter polycarbonate filters $(0.8 \mu \mathrm{m}$ pore size, Whatman catalogue no. 110409), pre-loaded in clean (flow-bench) conditions in the laboratory into in-line polycarbonate filter holders (Sartorius no. 16514E). Filters were preserved by drying in their filter hold- 
ers at $60^{\circ} \mathrm{C}$ for $48 \mathrm{~h}$ at sea and returned to the laboratory in clean dry boxes.

PIC samples were collected by sequential filtration for two size fractions. After pre-filtration through a $47 \mathrm{~mm}$ diameter $1000 \mu \mathrm{m}$ nylon mesh and supply pressure reduction to $137 \mathrm{kPa}$, seawater was filtered through a $47 \mathrm{~mm}$ diameter in-line $50 \mu \mathrm{m}$ nylon filter to collect foraminifera and then through a $47 \mathrm{~mm}$ diameter in-line $0.8 \mu \mathrm{m} \mathrm{GF} / \mathrm{F}$ filter (Whatman catalogue no. 1825-047) to collect coccolithophores. The flow path was split using a pressure relief valve set to $55 \mathrm{kPa}$, so that large volumes $(\sim 200 \mathrm{~L})$ passed the $50 \mu \mathrm{m}$ filter and only a small fraction of this volume $(\sim 15 \mathrm{~L})$ passed the $0.8 \mu \mathrm{m}$ filter. Filtration time was typically $2 \mathrm{~h}$. Volume measurement was done by either metering or accumulation. Based on visual examination, the high flow rate through the $50 \mu \mathrm{m}$ nylon mesh was sufficient to disaggregate faecal pellets and detrital aggregates. The flow rate data also suggest that filter clogging was uncommon (see the Supplement for an expanded discussion). While still in their holders, the filters were rinsed twice with $3 \mathrm{~mL}$ of $20 \mathrm{mM}$ potassium tetraborate buffer solution (for the first couple of voyages and later degassed deionized water) to remove dissolved inorganic carbon and were blown dry with clean pressurized air $(69 \mathrm{kPa})$. We consider that the short contact time of this rinse did not dissolve PIC, based on the sharp (non-eroded) features of coccolithophores collected in this way and examined by scanning electron microscopy (Cubillos et al., 2007). The filters were then removed from their holders, folded and inserted into Exetainer glass tubes (Labco catalogue no. 938W) and dried at $60^{\circ} \mathrm{C}$ for $48 \mathrm{~h}$ for return to the laboratory. In the following text, we refer to the GF/F filter sample results (which sampled the $0.8(\sim 1)$ to $50 \mu \mathrm{m}$ size fraction) as PIC01 and the nylon mesh sample fraction (which sampled the $50-1000 \mu \mathrm{m}$ size fraction) as PIC50.

\subsection{Sample analyses}

\subsubsection{Particulate organic carbon and nitrogen analysis}

The returned filter holders were opened in a laminar flow bench. Zooplankton were removed from the filters and the filters were then cleanly transferred into silver cups (Sercon catalogue no. SC0037), acidified with $50 \mu \mathrm{L}$ of $2 \mathrm{NHCl}$ and incubated at room temperature for $30 \mathrm{~min}$ to remove carbonates and dried in an oven at $60^{\circ} \mathrm{C}$ for $48 \mathrm{~h}$. The silver cups were then folded closed and the samples, along with process blanks (filters treated in the same way as samples but without any water flow on-board the ship) and casein standards (Elemental Microanalysis organic analytical standard catalogue no. B2155, batch 114859) were sent to the University of Tasmania Central Sciences Laboratory for CHN elemental analysis against sulfanilamide standards. Repeat samples collected sequentially at approximately $2 \mathrm{~h}$ intervals while the ship remained on station (station replicates) had a standard error of $7 \%(1 \mathrm{SD} n=10)$ and $8 \%(1 \mathrm{SD} n=10)$ for POC and PON, respectively. Importantly the processing blanks were large and variable and were corrected for separately for each voyage. For VL2 and VL3, POC process blanks averaged $25 \pm 6 \mu \mathrm{g} \mathrm{C}$ ( $1 \mathrm{SD}, n=2)$, equating to $20 \%$ of the average sample value. For VL4 and VL5, POC process blanks averaged $14 \pm 2 \mu \mathrm{g} \mathrm{C}(1 \mathrm{SD}, n=4)$, equating to $18 \%$ of the average sample value. For VL6 and VL7, POC process blanks averaged $23 \pm 3 \mu \mathrm{g} \mathrm{C} \mathrm{(} 1 \mathrm{SD} n=4)$, equating to $28 \%$ of the average sample value. For VL8 and VL9 POC process blanks averaged $14 \pm 1 \mu \mathrm{g} \mathrm{C} \mathrm{(} \mathrm{SD} n=4)$, equating to $14 \%$ of the average sample value.

\subsubsection{Biogenic silica analysis}

Biogenic silica was dissolved by adding $4 \mathrm{~mL}$ of $0.2 \mathrm{M}$ $\mathrm{NaOH}$ and incubating at $95^{\circ} \mathrm{C}$ for $90 \mathrm{~min}$, similar to the method of Paasche (1973). Samples were then rapidly cooled to $4{ }^{\circ} \mathrm{C}$ and acidified with $1 \mathrm{~mL}$ of $1 \mathrm{M} \mathrm{HCl}$. Thereafter, samples were centrifuged at $1880 \mathrm{~g}$ for $10 \mathrm{~min}$ and the supernatant was transferred to a new tube and diluted with $36 \mathrm{gL}^{-1}$ sodium chloride. Biogenic silica concentrations were determined by spectrophotometry using an Alpkem model 3590 segmented flow analyser and following USGS method I-2700-85 with these modifications: ammonium molybdate solution contained $10 \mathrm{gL}^{-1}\left(\mathrm{NH}_{4}\right)_{6} \mathrm{Mo}_{7} \mathrm{O}_{24}$, $800 \mu \mathrm{L}$ of $10 \%$ sodium dodecyl sulfate detergent replaced Levor IV solution, acetone was omitted from the ascorbic acid solution, and sodium chloride at the concentration of seawater was used as the carrier solution. Station replicates had a standard error of $9 \%(1 \mathrm{SD} n=9)$. The average blank values were $0.002 \pm 0.003 \mu$ moles per filter $(1 \mathrm{SD}, n=13)$ for nitrocellulose filters and $0.002 \pm 0.002 \mu$ moles per filter $(1 \mathrm{SD}, n=2)$ for polycarbonate filters, equating to 0.16 and $0.01 \%$ of average sample values, respectively.

\subsubsection{Particulate inorganic carbon analysis}

Particulate inorganic carbon samples were analysed by coulometry using a UIC CM5015 coulometer connected to a Gilson 232 autosampler and syringe dilutor. The samples were analysed directly in their gas-tight Exetainer collection tubes by purging for $5 \mathrm{~min}$ with nitrogen gas, acidification with $1.6 \mathrm{~mL}$ (PIC50 - 50 $\mu \mathrm{m}$ nylon filters) or $2.4 \mathrm{~mL}$ (PIC01 - GF/F filters) of $1 \mathrm{~N}$ phosphoric acid, and equilibration overnight at $40^{\circ} \mathrm{C}$. Samples were analysed the following day with a sample analysis time of $8 \mathrm{~min}$ and a dried carrier gas flow rate of $160 \mathrm{~mL} \mathrm{~min}^{-1}$. Calcium carbonate standards (Sigma catalogue no. 398101-100G) were either weighed onto GF/F filters or weighed into tin cups (Sercon catalogue no. SC1190) and then inserted into Exetainer tubes (some with blank nylon filters). Station replicates had standard errors of $18 \%(1 \mathrm{SD} n=11)$ and $13 \%$ (1 SD $n=11$ ) for PIC01 and PIC50, respectively. The average GF/F filter blank value was $-0.07 \pm 0.27 \mu \mathrm{g} \mathrm{C}(1 \mathrm{SD}$, $n=47$ ), equating to $-0.21 \%$ of average sample values, and 
it was $0.04 \pm 0.27 \mu \mathrm{g} \mathrm{C}(1 \mathrm{SD}, n=46)$ for nylon filters, equating to $0.05 \%$ of average sample values.

\subsection{Distinct sample collection and analytical methods used during V1}

\subsubsection{Distinct sample collection procedures for VL1}

For VL1, single samples were collected at each location by both sequential filtration and centrifugation of the underway supply over $1-3 \mathrm{~h}$. Despite the long collection times, these samples are effectively point samples because they were collected on station.

Sequential filtration was done using in-line $47 \mathrm{~mm}$ filter holders (Sartorius Inc.) holding three sizes of nylon mesh $(1000,200,50 \mu \mathrm{m})$ followed by a glass fibre filter (Whatman $\mathrm{GF} / \mathrm{F}, 0.8 \mu \mathrm{m}$ nominal pore size; muffled before use). These size fractions were intended to collect foraminifera (50$200 \mu \mathrm{m})$ and coccolithophores $(0.8-50 \mu \mathrm{m})$ and pteropods $(200-1000 \mu \mathrm{m})$, but the largest size fraction had insufficient material for analysis. The flow rate at the start of filtration was $25-30 \mathrm{Lh}^{-1}$ and typically dropped during filtration. The $0.8 \mu \mathrm{m}$ filter was replaced if flow rates dropped below $10 \mathrm{Lh}^{-1}$. Sampling typically took $3 \mathrm{~h}$. Quantities of filtered seawater were measured using a flowmeter (Magnaught M1RSP-2RL) with a precision of $\pm 1 \%$. After filtration, any remaining seawater in the system was removed using a vacuum pump. Filters were transferred to $75 \mathrm{~mm}$ Petri dishes inside a flow bench, placed in an oven (SEM Pty Ltd, vented convection) for 3-6h to dry at $60^{\circ} \mathrm{C}$ and stored in dark, cool boxes for return to the laboratory.

A continuous-flow Foerst-type centrifuge (Kimball Jr. and Ferguson Wood, 1964), operating at $18700 \mathrm{rpm}$, was used to concentrate phytoplankton from the underway system at a flow rate of $60 \mathrm{~L}$ per hour, measured using a water meter with a precision of $\pm 1 \%$ (Arad). Sampling typically took $1-3 \mathrm{~h}$. After centrifugation, $500 \mathrm{~mL}$ of deionized water was run through the centrifuge to flush away any remaining seawater and associated dissolved inorganic carbon. This was followed by $50 \mathrm{~mL}$ of ethanol to flush away the deionized water, ensure organic matter detached from the cup wall and speed subsequent drying. Inside a laminar flow clean bench, the slurry in the centrifuge head was transferred into a $10 \mathrm{~mL}$ polypropylene centrifuge tube (Labserve) and the material on the wall of the cup was transferred using $3 \mathrm{~mL}$ of ethanol and a rubber policeman. The sample was then centrifuged for $15 \mathrm{~min}$ and $3200 \mathrm{rpm}$, and the supernatant $(\sim 7 \mathrm{~mL})$ was removed and discarded. The vial was placed in the oven to dry for $12 \mathrm{~h}$ at $60^{\circ} \mathrm{C}$ and returned to the laboratory.

\subsubsection{Distinct analytical procedures for VL1 samples}

POC/PON analyses for the $0.8 \mu \mathrm{m}$ size fraction collected by filtration were done by packing five $5 \mathrm{~mm}$ diameter aliquots (punches) of the $47 \mathrm{~mm}$ diameter GF/F filters into acid- resistant $5 \times 8 \mathrm{~mm}$ silver cups (Sercon SC0037), treating these with two $20 \mu \mathrm{L}$ aliquots of $2 \mathrm{NHCl}$ to remove carbonates (King et al., 1998) and drying at $60^{\circ} \mathrm{C}$ for at least $48 \mathrm{~h}$. For the $50 \mu \mathrm{m}$ mesh filtration samples and the centrifuge samples, $0.5-1.0 \mathrm{mg}$ aliquots of the dried $\left(72 \mathrm{~h}\right.$ at $\left.60^{\circ} \mathrm{C}\right)$ centrifuge pellet remaining after PIC coulometry were encapsulated in $4 \times 6 \mathrm{~mm}$ silver cups (Sercon SC0036). Analyses of all these sample types was by catalytic combustion using a Thermo-Finnigan Flash 1112 elemental analyser calibrated against sulfanilamide standards (Central Sciences Laboratory, University of Tasmania). The precision of the analysis was $\pm 1 \%$. A blank correction of $0.19 \pm 0.09 \mu \mathrm{g} \mathrm{C}$ was applied, which represented $1.6 \%$ of an average sample.

PIC concentrations were determined for subsamples of the $0.8 \mu \mathrm{m} \mathrm{GF} / \mathrm{F}$ filters (half of the filter), the whole $50 \mu \mathrm{m}$ mesh screens and the whole centrifuge samples by closed system acidification and coulometry using a UIC CM5011 $\mathrm{CO}_{2}$ coulometer. The samples were placed in glass vials (or in the case of the centrifuge tubes connected via an adaptor), connected to a manual acidification unit and condenser and maintained at $40^{\circ} \mathrm{C}$ after acidification with $4 \mathrm{~mL}$ of 1 $\mathrm{NHCl}$ and swept with a nitrogen gas flow $\left(\sim 100 \mathrm{~mL} \mathrm{~min}^{-1}\right)$ via a drier and aerosol filter (Balston) into the coulometry cell. Calibration versus calcium carbonate standards (200 to $3000 \mu \mathrm{g}$ ) provided a precision of $\pm 0.3 \%$. However, for the $0.8 \mu \mathrm{m}$ filter, precision was limited to $10 \%$ by subsampling of the filter due to uneven distribution. Blank corrections were applied to the $0.8 \mu \mathrm{m}$ size fraction, being $2.4 \pm 1.8 \mu \mathrm{g} \mathrm{C}$ and representing $8.8 \%$ of an average sample. The $50 \mu \mathrm{m}$ fraction blank correction was $3.3 \pm 0.1 \mu \mathrm{g} \mathrm{C}$, representing $22 \%$ of an average sample. Centrifuge pellet coulometry blank subtraction was $2.0 \pm 0.1 \mu \mathrm{g} \mathrm{C}$, equivalent to $2.8 \%$ of an average sample.

Biogenic silica analysis of the residues remaining after PIC analysis of the centrifugation samples was by alkaline digestion $(0.2 \mathrm{~N} \mathrm{NaOH})$ in a $95^{\circ} \mathrm{C}$ water bath for $90 \mathrm{~min}$, similar to the method described by Paasche (1973) and as described in Sect. 2.2.2. with the variation that $4 \mathrm{~mL}$ of each sample was transferred from the centrifuge tubes and filtered using a syringe filter before dilution to $10 \mathrm{~mL}$.

\subsubsection{Comparison of VL1 to other voyages}

The first survey on VL1 in 2008 differed from later efforts in two important ways: (i) POC and PIC samples were collected by both filtration and centrifugation, (ii) separate $\mathrm{BSi}$ samples were not collected - instead BSi analyses were carried out only on the sample residues from PIC coulometric sample digestions of the centrifuge samples. Comparison of POC and PIC results from the centrifugation samples (effectively total samples without size fractionation) and the filtration samples (separated into the PIC01 0.8-50 $\mu \mathrm{m}$ and PIC50 $50-1000 \mu \mathrm{m}$ size fractions) shows (Fig. 2) that filtration collected somewhat more PIC (on the order of 20-30\%) and considerably more POC (on the order of 200-300\%) than 

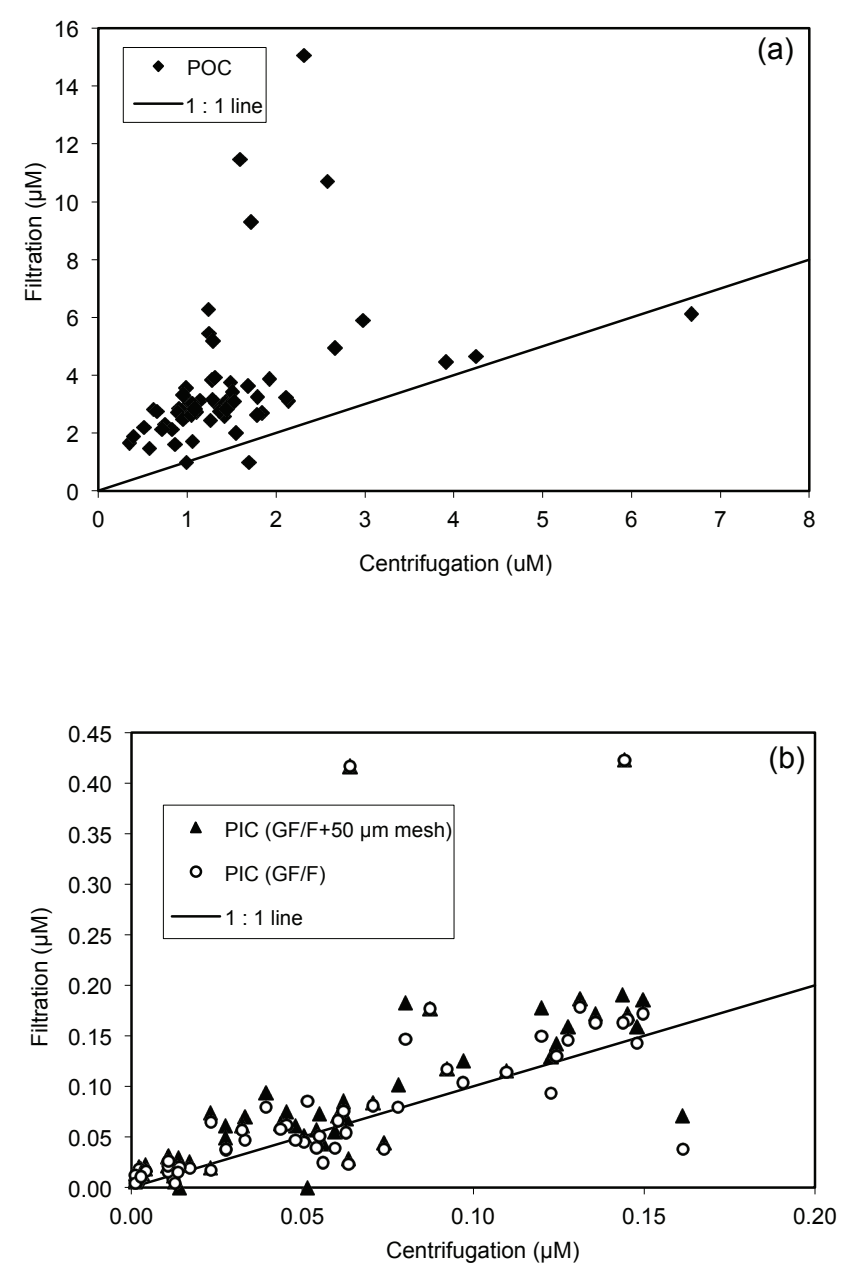

Figure 2. Comparison of centrifugation versus filtration sizefraction results for voyage leg 1: (a) centrifugation total POC versus filtration POC $(0.8-50 \mu \mathrm{m}$ fraction); (b) centrifugation total PIC versus filtration PIC01 $(0.8-50 \mu \mathrm{m})$ and PIC50 $(50-1000 \mu \mathrm{m})$ fractions.

centrifugation. This fits with the possibility of the loss of material from the continuous centrifuge cup, with a greater loss of lower-density organic matter (and a possible additional loss of organic matter via dissolution in the ethanol rinsing step). Thus, for a comparison of VL1 POC and PIC to the other voyages, we use only the filtration results, thereby avoiding methodological biases. For BSi, we do not have this possibility. Based on the low centrifuge yields for PIC and POC, we can expect that the VL1 BSi values are also too low. This is confirmed by comparison to the other voyages, which reveals that VL1 BSi values were lower than those of other voyages, especially in the far south where BSi values were generally highest (data shown below) but nonetheless had similar north-south latitudinal trends. For this reason, our further interpretation of the VL1 BSi results is only in terms of these latitudinal trends.

\subsection{Analysis of nutrients, dissolved inorganic carbon, alkalinity, and calculation of $\mathbf{p H}$ and calcite saturation}

Nutrients were analysed on-board ship for VL1 to VL5 and on frozen samples returned to land for VL6-9, all by the Commonwealth Scientific and Industrial Research Organisation (CSIRO) hydrochemistry group following WOCE/CLIVAR standard procedures, with minor variations (Eriksen, 1997), to achieve precisions of $\sim 1 \%$ for nitrate, phosphate and silicate concentrations. Dissolved inorganic carbon (DIC) and alkalinity samples were collected in gas-tight bottles poisoned with mercuric chloride and measured at CSIRO by coulometry and open-cell titration, respectively (Dickson et al., 2007). Comparison to certified reference materials suggests an accuracy and precision for both DIC and alkalinity of better than $\pm 2 \mu \mathrm{mol} \mathrm{kg}{ }^{-1}$. Full details have recently been published (Roden et al., 2016). Calculations of $\mathrm{pH}$ (free scale) and calcite saturation were based on the Seacarb version 3.1.2 software (https://CRAN.R-project. org/package=seacarb), which uses the default selection of equilibrium constants given in Van Heuven et al. (2011).

\subsection{Satellite-derived ocean properties and the NASA Ocean Biogeochemistry Model}

The locations of oceanographic fronts in the Australian sector were estimated from satellite altimetry, following the approach of Sokolov and Rintoul (2002), updated as follows. Absolute sea surface height ( $\mathrm{SSH}$ ) was calculated by adding the sea surface height anomaly from Archiving, Validation and Interpretation of Satellite Oceanographic data (AVISO+) (Pujol et al., 2016) to the $2500 \mathrm{dbar}$ reference level mean dynamic topography of Olbers et al. (1992). The positions of the fronts were then identified using the sea surface height contours corresponding to the positions of the Southern Ocean fronts identified by Sokolov and Rintoul (2007a) in the region $100-180^{\circ}$ E. From this analysis, we show eight fronts from north to south consisting of the following.

- Fronts 1-3: north, middle and south branches of the Subantarctic Front (SAF), which bound the highestvelocity jets of the Antarctic Circumpolar Current (ACC).

- Fronts 4-6: north, middle and south branches of the Polar Front (PF), associated with subsurface temperature features related to the strength of the ACC and with the shoaling of Circumpolar Deep Water (CDW) in the overturning circulation. The Polar Frontal Zone (PFZ) lies between the northernmost of these branches and the SAF to its north.

- Fronts 7-8: north and south branches of the Southern Antarctic Circumpolar Current Front (sACCf) front, 
marking weaker flows in Antarctic waters of the ACC and occurring near where upwelling of old nutrient-rich and relatively acidic Circumpolar Deep Water comes closest to the surface.

We do not show the Subtropical Front (STF), which marks the northern boundary of the Southern Ocean, or the Southern Boundary Front, which marks the southern edge of the ACC (separating it from westerly flow in Antarctic shelf waters). This is because both features have weak, discontinuous SSH signatures south of Australia: mesoscale eddies rather than the STF dominate the weak SSH field in the Subantarctic Zone (SAZ; between the STF and the SAF), and the detection of the Southern Boundary Front is confounded by proximity to the Antarctic shelf, where altimetry is impacted by other processes, including sea-ice cover for much of the year (Sokolov and Rintoul, 2007a).

We considered using these dynamic heights and front locations as ordinates for the spatial distributions of POC, PIC and BSi. In the core of the ACC $\left(50-60^{\circ} \mathrm{S}\right)$, this did help explain some departures from monotonic north-south trends as resulting from meanders of the fronts, but latitude was more strongly correlated with PIC abundance in the SAZ and with BSi in southern ACC waters and Antarctic shelf waters, where dynamic height contours were only weakly varying. Accordingly, there was no overall advantage of replacing latitude by dynamic height as a predictor of biogenic mineral concentrations, and we have used latitude as the ordinate in our figures and discussion.

Sea surface temperatures $\left({ }^{\circ} \mathrm{C}\right)$ - e.g. see Fig. 1 - were obtained from the NASA MODIS Aqua $11 \mu \mathrm{m}$ night-only L3m product available online:

https://giovanni.gsfc.nasa.gov/giovanni/\#service= TmAvMp\&starttime $=\&$ endtime $=\&$ data $=$ MODISA_L3m SST_2014_nsst\&variableFacets=dataFieldMeasurement $\%$ 3ASea\%20Surface\%20Temperature\%3B

We chose the night values to avoid shallow ephemeral structures arising from daytime solar heating. We refer to these estimates simply as sea surface temperature (SST) values.

Phytoplankton chlorophyll concentrations (Chl in $\mathrm{mg} \mathrm{m}^{-3}=\mu \mathrm{gL}^{-1}$ ) were obtained from the NASA MODIS Aqua $\mathrm{L} 3 \mathrm{~m}$ product available online: https://giovanni. gsfc.nasa.gov/giovanni/\#service $=\mathrm{TmAvMp \& starttime=}$ \&endtime $=\&$ data $=$ MODISA_L3m_CHL_2014_ chlor_a\&variableFacets $=$ dataFieldMeasurement $\%$

3AChlorophyll\%3B (NASA Goddard Space Flight Center, 2014a).

The algorithm relies on the blue/green reflectance ratio for Chl values above $0.2 \mu \mathrm{gL}^{-1}$ and incorporates stray light correction based on the difference between red and blue light reflectances at lower $\mathrm{Chl}$ levels. This product has been suggested to underestimate chlorophyll in the Southern Ocean south of Australia (Johnson et al., 2013) but has the advantage of ongoing ready availability. For this reason, we use it only for context and not for any detailed comparisons to shipboard observations. We refer to these estimates as satellite chlorophyll ( $\mathrm{SChl}$ ) values.

Particulate inorganic carbonate concentrations $\left(\mathrm{mol} \mathrm{m}^{-3}\right)$ based on backscatter magnitudes (Balch et al., 2005) were obtained from the NASA MODIS Aqua ocean colour product available online: https://oceancolor.gsfc.nasa.gov/cgi/13/A20111212011151. L3m_MO_PIC_pic_9km.nc.png?sub=img (NASA Goddard Space Flight Center, 2014b).

We refer to these estimates as SPIC values. The veracity of these estimates in the Southern Ocean remains an active area of research. PIC sampling in the subantarctic South Atlantic found levels 2-3 times lower than the satellite estimates (Balch et al., 2011), and the algorithm also produces surprisingly high estimates in Antarctic waters, where limited shipboard surveys suggest that coccolithophore abundances drop strongly (work summarized in Balch et al., 2005). Our data provide the most extensive PIC observations for comparison to SPIC values in Antarctic waters yet available, and this is discussed in detail below. The comparison of PIC and SPIC values at individual sampling sites was based on combined data from MODIS Aqua and Terra $9 \mathrm{~km}$ daily products. SPIC values were an average of pixels within $25 \mathrm{~km}$ of PIC sampling sites on the same day.

The phytoplankton function type model is based on Gregg and Casey (2007a). Details of particular relevance to comparisons with our observations are discussed in Sect. 3.4.

\section{Results and discussion}

\subsection{Representativeness of oceanographic sampling}

As shown in Fig. 1, sampling covered all Southern Ocean zones from subtropical waters in the north to seasonally sea-ice-covered waters in the south (covering SST ranging from -1 to $23^{\circ} \mathrm{C}$ ). Almost all samples were representative of high-nutrient low-chlorophyll Southern Ocean waters, indicative of iron limitation. Exceptions occurred near Tasmania, where moderate levels of SChl were occasionally present, and over the Antarctic shelf where locally very high levels of SChl were present. Individual maps for each voyage leg of SChl are provided in the Supplement and those of satellite reflectance-based estimates of PIC (SPIC) are found below, and they reveal that higher values of SChl and SPIC are often associated with mesoscale structures, especially in the Subantarctic and Polar Frontal zones. This means that mesoscale variability makes satellite-versus-shipboard comparisons difficult, and this problem is exacerbated by frequent cloud cover. Both techniques characterize the very upper water column, with ship samples from $\sim 4 \mathrm{~m}$ depth and the satellite ocean colour observations reflecting the efolding penetration depth of $\sim 10-15 \mathrm{~m}$ (Grenier et al., 2015; Morel and Maritorena, 2001). 


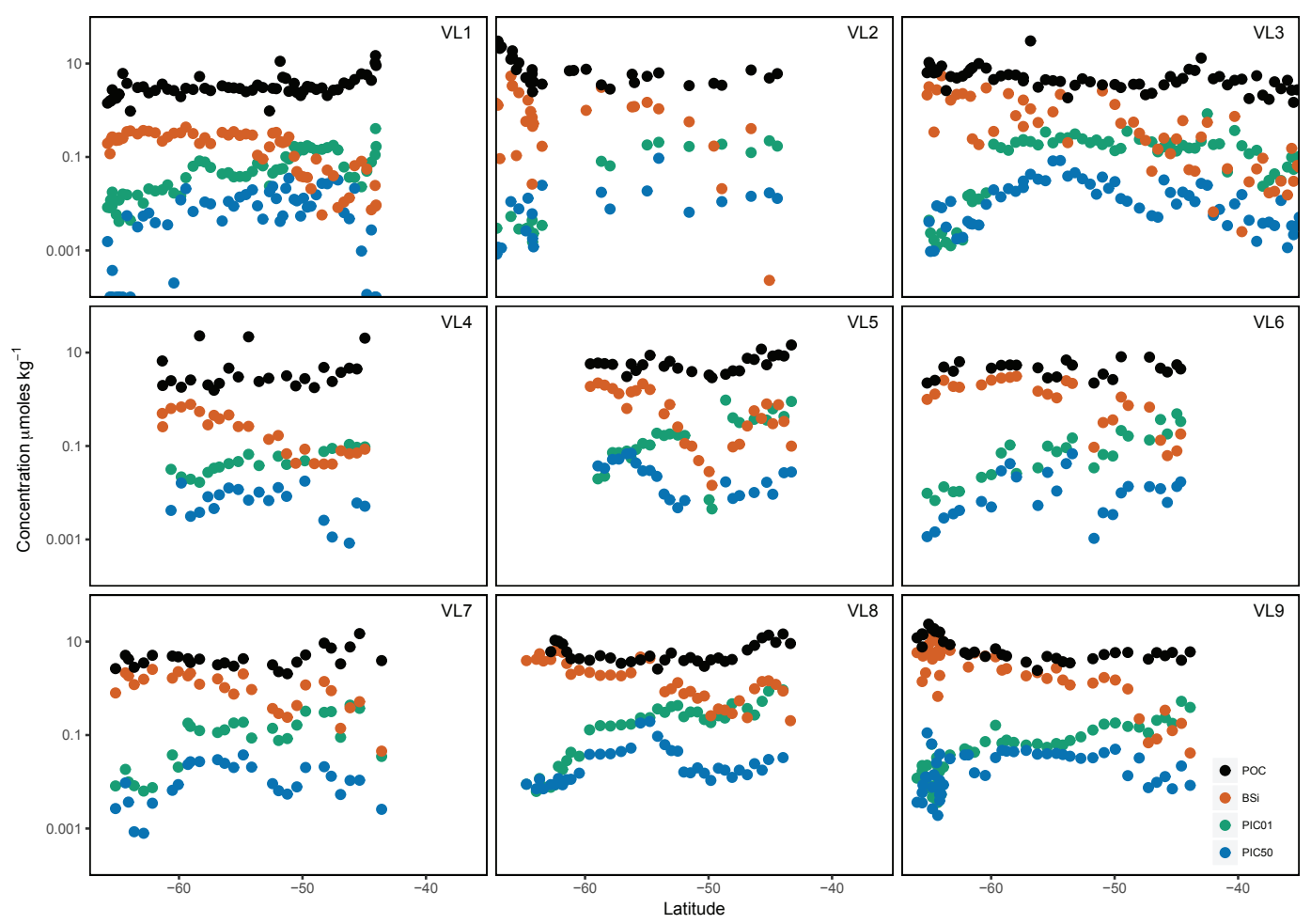

Figure 3. Latitudinal variations in POC, BSi, PIC50 and PIC01 concentrations for each voyage leg. See Table 1 for voyage leg details and Fig. 1 for sample sites.

It appears likely that our single-depth sampling can be considered as representative of upper water column phytoplankton concentrations because pigment samples and profiles of beam attenuation and nighttime fluorescence from some of these voyages as well as previous work show that biomass is generally well mixed in the upper water column and that when subsurface chlorophyll maxima are present they primarily reflect increased chlorophyll levels rather than increased phytoplankton abundances (Bowie et al., 2011a, b; Parslow et al., 2001; Rintoul and Trull, 2001; Shadwick et al., 2015; Trull et al., 2001b; Wright et al., 1996; Wright and van den Enden, 2000). This perspective is also consistent with the limited information on the depth distributions of coccolithophores in the Southern Ocean, which generally exhibit relatively uniform and maximal values (especially for the most abundant species, Emiliania huxleyi) within the surface mixed layer (Findlay and Giraudeau, 2000; Holligan et al., 2010; Mohan et al., 2008; Takahashi and Okada, 2000). There is some evidence that this conclusion can also be applied to the PIC50 foraminiferal fraction, in that the most abundant of these organisms tend to co-locate with phytoplankton in the mixed layer in the Southern Ocean (Mortyn and Charles, 2003).

\subsection{Latitudinal distributions of BSi, PIC and POC}

All the voyage legs exhibited similar latitudinal variations in the measured chemical components (Fig. 3). BSi, predominantly derived from diatoms, was clearly the dominant biogenic mineral in the south in Antarctic waters. PIC01 concentrations, predominantly derived from coccolithophores, were highest in northern subantarctic waters, although even there BSi was often present at similar levels. Interestingly, PIC50 concentrations, predominantly derived from foraminifera, often exhibited maxima in the middle of the Southern Ocean at latitudes of $55-60^{\circ} \mathrm{S}$. The latitudinal variations in all these biogenic mineral concentrations were quite strong, exceeding 2 orders of magnitude. In contrast, variations in POC were 10-fold smaller and often quite uniform across the central Southern Ocean, with maxima sometimes in the far north near Tasmania and sometimes in the far south over the Antarctic shelf (Fig. 3). Variations in BSi, PIC and POC concentrations among the voyages, at a given latitude, were smaller than these north-south trends. It seems likely that these smaller variations were partly seasonal, in that the earliest seasonal voyage leg (VL4 in September) had lower concentrations of every component. But across the other voyages, ranging from mid-November (VL5) to mid-April (VL1), no clear seasonal cycle was exhibited, perhaps owing to variations in sampling location, and the known importance of interannual and mesoscale structures in Southern Ocean 


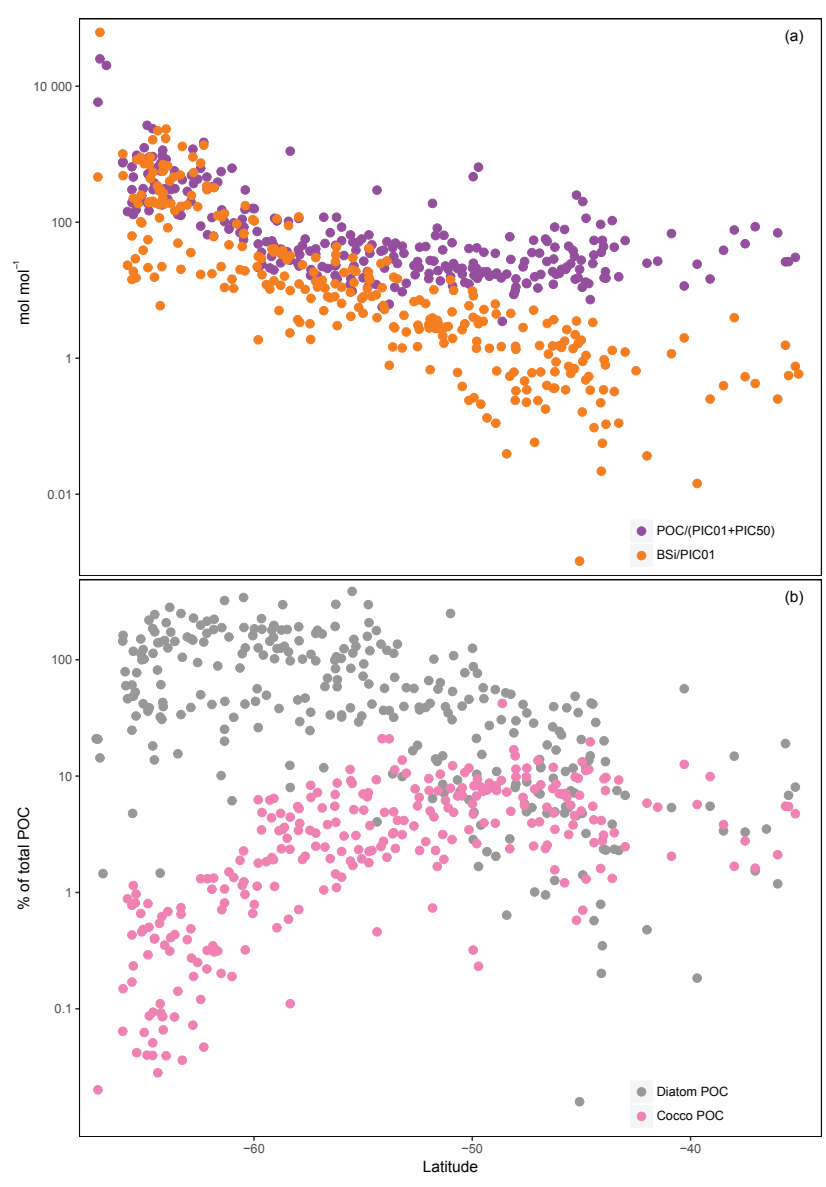

Figure 4. Latitudinal variations in the dominance of diatoms versus coccolithophores and their contributions to total POC for results combined from all voyages: (a) BSi/PIC01 and POC / (PIC50 + PIC01) ratios; (b) percent contributions to total $\mathrm{POC}$ attributable to diatoms (assuming $\mathrm{POC} / \mathrm{BSi}=3.35$ ) and coccolithophores (assuming POC / PIC01 $=0.833$ ).

phytoplankton distributions (e.g. Moore et al., 1999; Moore and Abbott, 2002; Sokolov and Rintoul, 2007b). As noted in the Sect. 2.3, the BSi values for VL1 stand out as being too low, in that they were well below those of other voyages, while the POC, PIC01 and PIC50 values were similar.

The latitudinal dependence of the relative importance of diatoms and coccolithophores is revealed by viewing the $\mathrm{BSi} / \mathrm{PIC} 01$ ratios as an ensemble for all the voyages (the use of the ratio helps to remove seasonal and interannual variations in their abundances, which tend to track each other at a given latitude). The BSi/PIC01 ratio reaches values of 200 in the far south and decreases north of $50^{\circ} \mathrm{S}$ to values near 1 (Fig. 4a). The approximate equivalence of $\mathrm{BSi}$ and PIC01 occurs relatively far north in the Southern Ocean, near $50^{\circ} \mathrm{S}$, and thus near the southern edge of the Subantarctic Zone. This persistence of the importance of diatoms as a major component of the phytoplankton community in northern waters of the Southern Ocean must reflect the wintertime renewal of silica supply from upwelled deep waters in the Southern Ocean that are carried north by Ekman transport, combined with the recycling of biogenic silica within surface waters, given that by midsummer silicate is largely depleted north of the Subantarctic Front (Nelson et al., 2001; Trull et al., 2001b). Accordingly the relative dominance of diatoms and coccolithophores in the SAZ may be quite sensitive to changes in the overturning circulation and westerly wind field. How this might translate into impacts on the biological carbon pump remains far from clear. Interestingly, deep ocean sediment traps in the SAZ south of Australia reveal a strong dominance (4-fold) of PIC over BSi in the export flux to the ocean interior, reminding us that export can be selective (and also that foraminifera can contribute a significant fraction of total PIC, estimated to vary from $\sim 1 / 3$ to 2/3; King and Howard, 2003). The POC flux recovered by these deep sediment traps was close to the global median and similar to that of biogenic silica-dominated fluxes in the Polar Frontal Zone to the south (Trull et al., 2001a).

The importance of diatoms across the entire Southern Ocean, relative to coccolithophores, is further emphasized by expressing their biogenic mineral abundances in terms of associated POC, using average values for the POC/BSi ratio of iron-limited diatoms (3.35, equivalent to a $\mathrm{Si} / \mathrm{N}$ ratio of 2 and a Redfield C / N ratio of 6.7; Ragueneau et al., 2006; Takeda, 1998) and the POC / PIC ratio of coccolithophores (1.5, for Emiliania huxleyi morphotype A, the dominant Southern Ocean species; Bach et al., 2015; Muller et al., 2015). As shown in Fig. 4b, this suggests that diatoms dominate the accumulation of organic carbon throughout the Southern Ocean, with coccolithophores generally contributing less than half that of diatoms in the SAZ and less than a tenth of that in Antarctic waters. This statement is of course limited to POC captured by our small-volume, size-limited $(1-1000 \mathrm{~mm})$ sampling procedure, and variability in the extent of dominance and the scaling of POC to biogenic minerals still allows significant contributions from other POC sources. The relatively small POC contribution from coccolithophores is only weakly sensitive to the $\sim 3$-fold variation (Muller et al., 2015) of POC / PIC ratios among Emiliania huxleyi morphotypes. Using the lower value of 0.83 observed for over-calcified forms that occur in the northern SAZ would reduce the POC contribution there but still leave it co-dominant with diatoms, and using the higher value of 2.5 observed for polar morphotype $\mathrm{C}$ would increase the POC contribution in Antarctic waters but still leave it overwhelmed by the diatom contribution (Fig. 4b). The relative contributions to total POC are also sensitive to the POC / BSi ratio chosen for diatoms (which vary significantly across genera; Ragueneau et al., 2002, 2006). For these reasons, the relative dominance is best viewed on the log scale of Fig. $4 \mathrm{~b}$ and while keeping in mind the considerable scatter.

Figure $4 \mathrm{~b}$ also emphasizes that total POC contents can be largely explained by diatom biomass in Antarctic waters (south of $50^{\circ} \mathrm{S}$ ), whereas in the SAZ (north of $50^{\circ} \mathrm{S}$ ), total 
POC often exceeds the sum of contributions from diatoms and coccolithophores. This serves as an important reminder that other organisms are important to the carbon cycle in the SAZ, and phytoplankton functional type models should avoid overemphasis on diatoms and coccolithophores just because they have discernable biogeochemical impacts (on silica and alkalinity, respectively) and satellite remote-sensing signatures (Hood et al., 2006; Moore et al., 2002). Finally, we note that the relatively low levels of PIC across the Southern Ocean as observed here means that POC / PIC ratios are high - greater than 4 in the SAZ and ranging up to 20 in Antarctic waters (Fig. 4a). This suggests that calcification has a negligible countering impact on the reduction of surface ocean $\mathrm{CO}_{2}$ partial pressure by phytoplankton uptake, even smaller than the influence of a few percent to $\sim 10 \%$ identified earlier from deep sediment trap compositions in high-nutrient, low-chlorophyll (HNLC) (Boyd and Trull, 2007a) and ironenriched waters, respectively (Salter et al., 2014).

Notably, our Southern Ocean PIC01 estimates are smaller than those found in Northern Hemisphere polar waters. As compiled by Balch et al. (2005), concentrations were 100fold higher $(\sim 10 \mu \mathrm{M})$ in the north Atlantic south of Iceland $\left(60-63^{\circ} \mathrm{N}\right)$ than any of our values and 1000 -fold higher than our values in the same Southern Hemisphere latitude range. Values collected over many years from the Gulf of Maine (Balch et al., 2008) were $\sim 1 \mu \mathrm{M}$ and thus 5-10 times higher than our SAZ values (Gulf of Maine summer temperatures are similar to the SAZ, and temperatures are colder in winter). This difference between hemispheres is also evident in observations from the South Atlantic, where PIC values estimated from acid labile backscatter for six voyages between 2004 and 2008 and latitudes $40-50^{\circ} \mathrm{S}$ were $\sim 0.1-0.5 \mu \mathrm{M}$ in remote waters (Balch and Utgoff, 2009), increasing to $1-2 \mu \mathrm{M}$ in the Argentine Basin with a few values reaching $4 \mu \mathrm{M}$ (Balch et al., 2014). These high South Atlantic observations are the highest of the Great Calcite Belt, identified as a circumpolar feature of subantarctic waters based on SPIC values (Balch et al., 2014, 2011). Notably, shipboard PIC measurements in this feature are 2-3 times lower than the SPIC estimates in the South Atlantic (Balch et al., 2011), and ship-collected samples from two voyages across the South Atlantic and Indian sectors (Balch et al., 2016) exhibit PIC concentrations (actual PIC values accessed online at http://www.bco-dmo.org/dataset/560357, rather than the PIC estimates from acid-labile backscatter shown in the paper) that decrease eastwards in this feature to reach values close to our observations in the Australian sector of $\sim 0.1 \mu \mathrm{M}$ (Fig. 3).

\subsection{Comparison to satellite PIC (SPIC) estimates}

As is very evident from the limited observations we have achieved from our efforts over many years, it will never be possible to characterize Southern Ocean phytoplankton population dynamics from ship-based sampling - the influences of mesoscale circulation, ephemeral inputs of the limiting nutrient iron and food web dynamics produce variability that cannot be adequately assessed in this way, leaving sparse sampling open to potentially large biases. The use of satellite observations is clearly the path forward to alleviate this problem, and the development of algorithms for global coccolithophore distributions has been a major advance (Balch et al., 2005; Brown and Yoder, 1994). Until recently the calibration of these SPIC values has been based primarily on North Atlantic observations. Work to check these efforts for the Southern Ocean has begun but remains sparse. Early work in the South Atlantic found that SPIC values appeared to exceed ocean PIC by a factor of 2-3 (Balch et al., 2011), and based on a handful of samples, it was suggested that this might reflect a lower amount of PIC per coccolith (Holligan et al., 2010), and it has since been confirmed that polar coccolithophores can have low PIC contents (Charalampopoulou et al., 2016; Muller et al., 2015; Poulton et al., 2011). Two dedicated voyages to investigate the Great Calcite Belt in the SAZ and PFZ across the South Atlantic and south Indian oceans attempted a comparison of acid-labile backscatter (as a proxy for PIC) and MODIS SPIC values, but there were no matchups in the South Atlantic owing to cloudy conditions (Balch et al., 2016). Results from the South Indian sector and from other voyages in the South Atlantic show high acidlabile backscatter, which translates into high SPIC estimates in the SAZ and PFZ (especially in naturally iron-fertilized waters) but also high values further south which are not in agreement with ship observations (Balch et al., 2016; Smith et al., 2017).

The comparison of our ship observations to MODIS SPIC estimates are shown in Fig. 5 for each voyage leg. These reveal some agreement in the SAZ in terms of identifying moderate levels of PIC, often in association with higher levels of total SChl (Supplement) but differ strongly in Antarctic waters where all ship observations reveal low PIC values, whereas the SPIC estimates in Antarctic waters reach and often exceed those in the SAZ, especially over the Antarctic shelf. Both cloudy conditions and strong mesoscale variability limit the number of direct comparisons (matchups) that can be made. Using a matchup length scale of $25 \mathrm{~km}$ (i.e. the ship and satellite observations must be within $25 \mathrm{~km}$ of each other on the same day), which is somewhat larger than the correlation length scale for chlorophyll in the Southern Ocean of 10-15 km (Haëntjens et al., 2017), allowed us to retain 116 matchups. These results, shown in Fig. 6, confirm that the satellite SPIC values are reasonable estimates in subantarctic waters, within a factor of 2-3 (Balch et al., 2011), but very much too high in Antarctic waters.

\subsection{Comparison to possible environmental controls on coccolithophore growth rates}

The ship observations provided here offer a significant advance in quantifying the distributions of coccolithophores in 


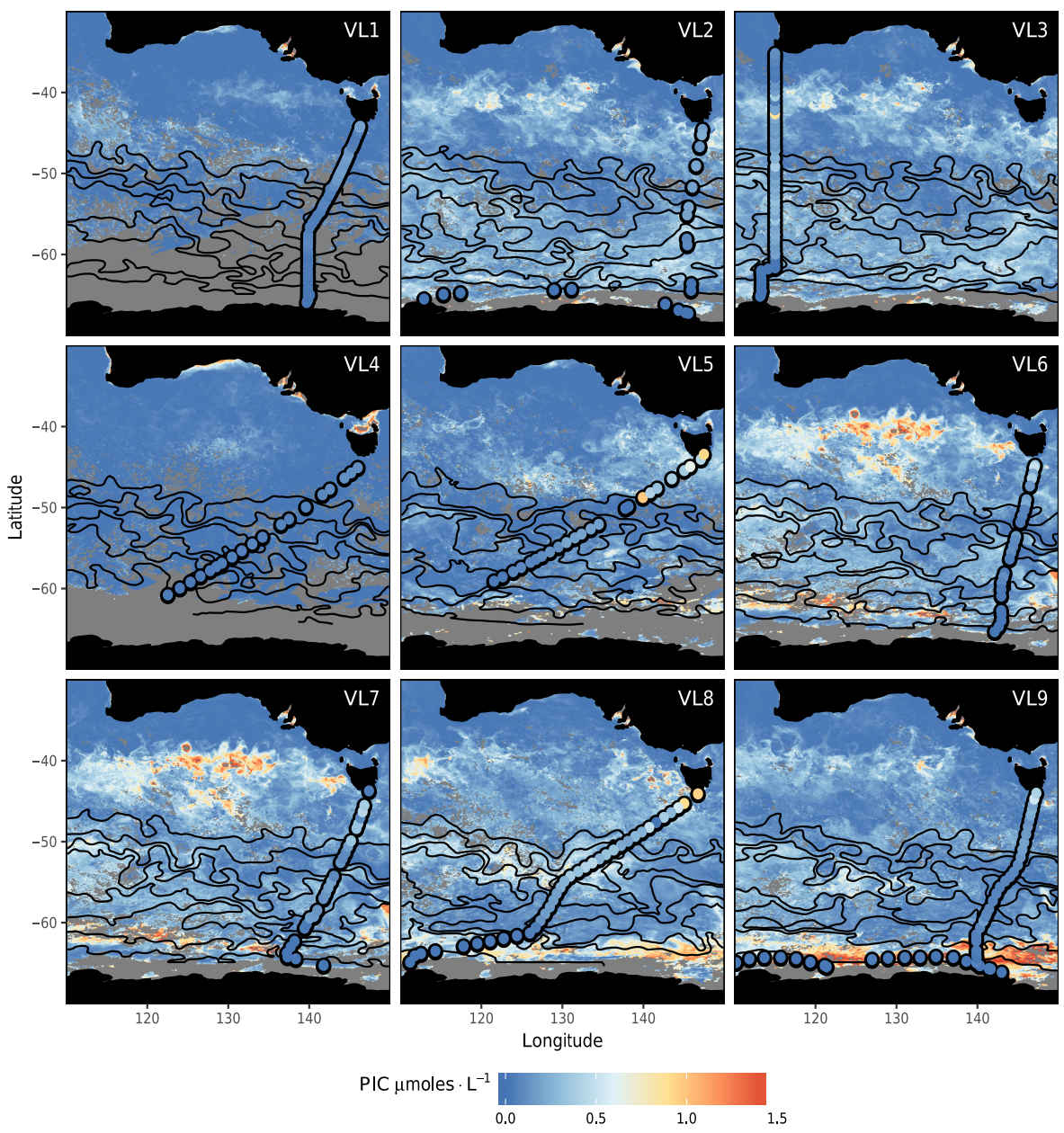

Figure 5. Maps comparing ship-based distributions of coccolithophore PIC distributions (PIC01; coloured dots) with satellite PIC estimates (SPIC; background colours) for each voyage leg. The SPIC estimates are averages for the month preceding the start of each voyage leg. Contour lines indicate dynamic height-determined frontal positions for the week preceding the each voyage leg (see Fig. 1 for front nomenclature).

the Southern Ocean south of Australia but much less understanding of why these distributions arise and therefore how they might change in response to climate, circulation and biogeochemical changes in the future. Coccolithophores, especially the most common species Emiliania huxleyi, have been studied sufficiently in the laboratory to allow possible important controls on their niches and especially their calcification rates to be proposed, including temperature, $\mathrm{pH}, p \mathrm{CO}_{2}$, calcite saturation state, light, and macro- and micronutrient availability (Bach et al., 2015; Feng et al., 2016; Mackinder et al., 2010; Muller et al., 2015; Müller et al., 2017; Schlüter et al., 2014; Schulz et al., 2007; Sett et al., 2014; Zhang et al., 2015). We collected observations of many of these properties in parallel with our PIC observations and now briefly examine whether they present correlations that might contribute to understanding why coccolithophores are found mainly in northern subantarctic waters and not further south. For illustrative purposes, we focus on VL3 (the mid- to late sum- mer I9 northward hydrographic section from Antarctica to Perth) and VL6 (the early summer to midsummer southward l'Astrolabe transit from Tasmania to Antarctica). VL3 covered the widest range of physical properties and exhibited PIC01 concentrations that remained elevated further south than any other voyage (Fig. 3). VL6 exhibited the more typical PIC01 distribution of a close to continuous decrease southward (Fig. 3). The results from the other voyage legs were very similar to VL3 (figures not shown; data available in the Supplement).

Many properties that might influence coccolithophore productivity decreased strongly and close to monotonically from north to south across the Southern Ocean for our voyages (Fig. 7). These include temperature (from 23 to $-0.4{ }^{\circ} \mathrm{C}$ for our samples), salinity (from 35.6 to 33.6, with a close correlation with alkalinity; not shown - data available in the Supplement), $\mathrm{pH}$ (from 8.20 to 8.08 on the free scale) and the saturation state of calcite (from 5.22 to 2.12). The strong 


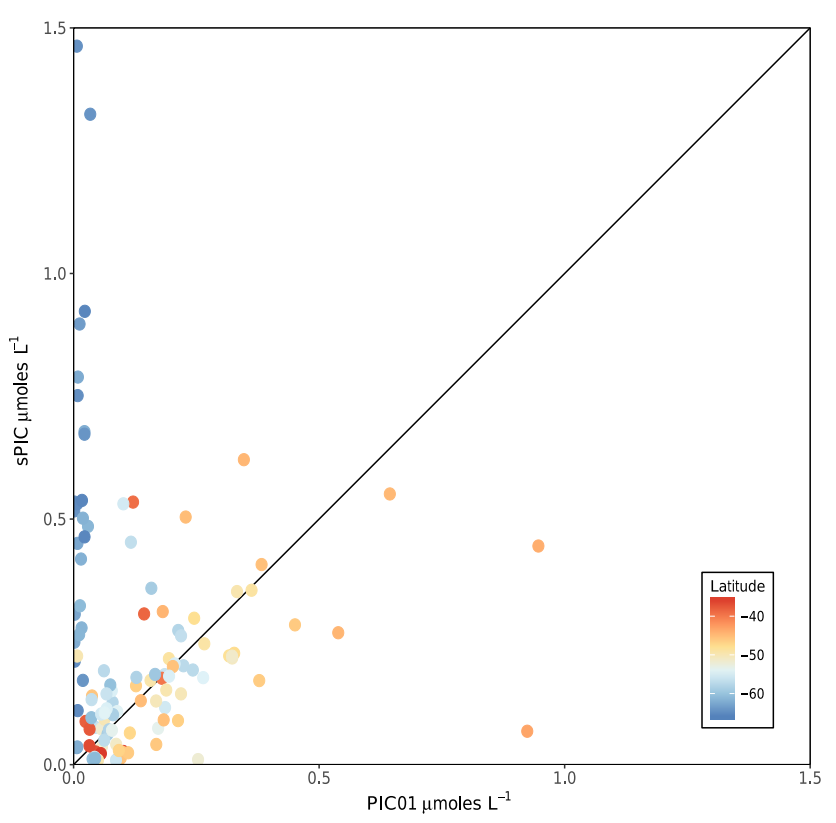

Figure 6. Comparison of satellite SPIC and ocean PIC concentrations for the 116 matchups for which satellite SPIC estimates were available within $25 \mathrm{~km}$ of the ocean PIC sample sites, on the same day. Colours indicate sample latitudes and show that good correlation occurs in subantarctic waters, but there is a strong overestimation by the satellite technique in Antarctic waters.

correlation of these properties means that it is not easy to separate their possible influences on coccolithophore distributions without relying on specific thresholds or quantitative response models. This problem of correlations among drivers has been noted before in examining transect data across the Drake Passage, where more detailed measurements of coccolithophore properties augmented with incubation studies found that temperature and light were the most probable drivers of coccolithophore abundance and calcification rates (Charalampopoulou et al., 2016). Our lack of information on the availability of light (mixed layer depth was determined only on the two hydrographic sections), iron, or individual species and strains makes deducing a possible influence of ocean acidification on coccolithophore distributions from our spatial distribution data even more difficult. Nonetheless, we offer a few pertinent observations. Firstly, the change in PIC01 abundances with latitude is much larger than expected from models of the responses of calcification rates (normalized to maximum rates) to inorganic carbon system variations (Fig. 7). Two models are shown:

1. The "Bach model" based on independent terms for sensitivity to bicarbonate, $\mathrm{CO}_{2}$ and $\mathrm{pH}$. It fits quite well the results from many laboratory incubations of Emiliania huxleyi strains under conditions of modern and elevated $p \mathrm{CO}_{2}$ (Bach et al., 2015), and we have used values for the constants $(a, b, c, d)$ obtained from incubations of a strain isolated from subantarctic waters south of Tasmania (Müller et al., 2017) to provide what might be considered the best current model for the calcification rate response to changing inorganic carbon abundance and speciation, following Eq. (1):

Bach relative calcification rate

$$
=a\left[\mathrm{HCO}_{3}^{-}\right] /\left(b+\left[\mathrm{HCO}_{3}^{-}\right]\right)-e^{-c\left[\mathrm{CO}_{2}\right]}-d\left[\mathrm{H}^{+}\right] .
$$

2. The "Langdon model" based on a simple, inorganic precipitation-motivated parameterization of calcification as a function of calcite saturation state $\Omega$ (Gattuso et al., 1998; Langdon et al., 2000), which has been shown to apply in an approximate way to many corals (Anthony et al., 2011; Silverman et al., 2007) and perhaps to Southern Ocean foraminifera (Moy et al., 2009). We have chosen the simple linear form $(n=1)$ and a sensitivity at the top end of the observed range $(a=1 / 4$, so that the calcification rate varies linearly from 0 to 1 for $\Omega=1$ to 4 ), following Eq. (2):

$$
\text { Langdon relative calcification rate }=a(\Omega-1)^{n} .
$$

As shown in Fig. 7, both these calcification rate models exhibit limited variations with latitude in the Southern Ocean. The Bach model suggests a negligible change in the calcification rate. This is essentially because the Southern Ocean variations in bicarbonate, $\mathrm{CO}_{2}$ and $\mathrm{pH}$ are very small compared to the future expected values used in incubation experiments. In addition, southward cooling causes $\mathrm{pH}$ to rise, offsetting the impact of a southward decrease in salinity and alkalinity, thus reducing the southward decrease in $\mathrm{pH}$ and the associated drop in the modelled calcification rate. The Langdon model suggests an approximately 3 -fold decrease in the calcification rate, which is considerably smaller than the more than 10-fold drop in PIC01 (shown on a linear scale in Fig. 7 and a logarithmic scale in Fig. 3). The shape of the Langdon model decrease shows some agreement with that of PIC01 for VL6 but none for VL3 (which exhibits relatively constant significant PIC01 concentrations in the $40-50^{\circ} \mathrm{S}$ latitude range where the Langdon model shows a strong decrease in the calcification rate, and then a strong drop in PIC01 south of $60^{\circ} \mathrm{S}$, where the Langdon model shows no change). Thus, and unsurprisingly, coccolithophore abundances are clearly not controlled by inorganic carbon chemistry alone. This perspective has been strongly emphasized previously, including by Bach et al. (2015), who noted "great care must be taken when correlating carbonate chemistry with coccolithophore dispersal because this is by no means the only parameter controlling it. Physical (e.g. temperature), other chemical (e.g. nutrient concentrations), or ecological (e.g. grazing pressure) factors will under many if 

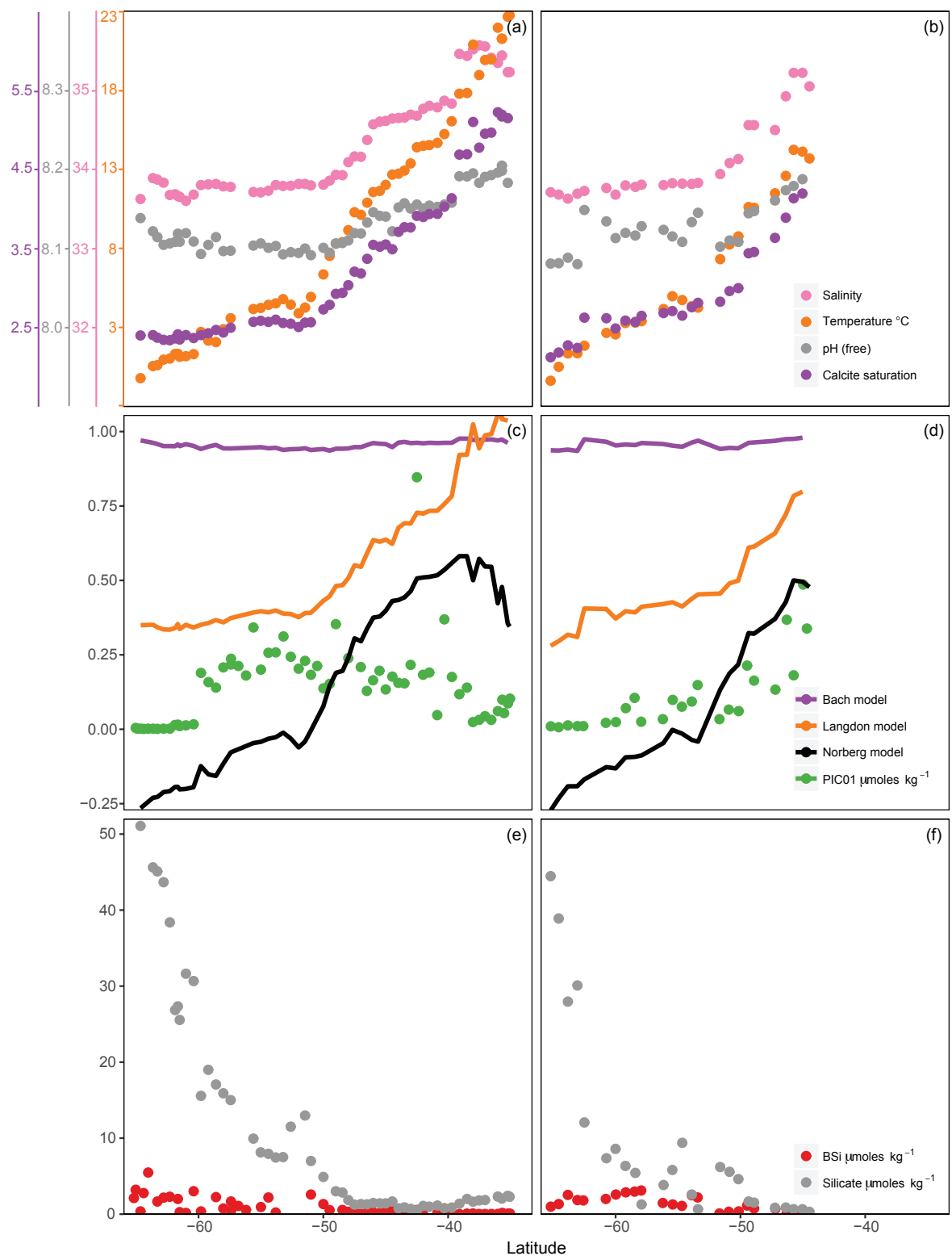

Figure 7. Latitudinal environmental conditions for voyage leg VL3 (left panels) and voyage leg VL6 (right panels): (a, b) T, S, pH (free scale), calcite saturation; (c, d) PIC01, Bach and Langdon relative calcification rate (dimensionless), and Norberg growth rate ( $\mathrm{d}^{-1}$ ) models; (e, f) $\mathrm{BSi}$ and $\mathrm{Si}(\mathrm{OH})_{4}$ concentrations $(\mu \mathrm{M})$.

not most circumstances outweigh the influence of carbonate chemistry conditions".

Many laboratory studies have emphasized the importance of temperature on coccolithophore growth rates, as compiled recently (Feng et al., 2016), and warming has been suggested as a possible cause of decadal northward apparent range expansion in the North Atlantic (Rivero-Calle et al., 2015) and the occurrence of unusual blooms in the Bering Sea (Merico et al., 2004). To provide a brief visualization of the expected univariate response, we fit the "Norberg" thermal optimum envelope model (Norberg, 2004) to growth rate data for 5- $25^{\circ} \mathrm{C}$ with modern $p \mathrm{CO}_{2}$ and nutrient-replete conditions for a Southern Ocean morphotype A strain of Emiliania huxleyi, isolated from south of Tasmania (Muller et al., 2015), with optimum temperature $z=15$, thermal window $w=10$ and scaling constant $a$, in which the exponential term represents the broad global temperature dependence of generic phytoplankton growth rates (Eppley, 1972) and produces the known skewed form of organismic thermal tolerances, following Eq. (3):

Norberg growth rate $\left(\mathrm{d}^{-1}\right)=a\left[1-((T-z) / w)^{2}\right] e^{0.0633 T}$. 
As shown in Fig. 7, this predicts a drop from $\sim 0.5 d^{-1}$ at the northern edge of the Southern Ocean to zero growth near $\sim 53^{\circ} \mathrm{S}$, whereas PIC01 concentrations fall off more slowly further south. The presence of other morphotypes with lower thermal optima (Cubillos et al., 2007) is an easy possible way to explain this difference. Overall the Norberg temperature model has an advantage of the calcification rate models - it does predict a strong decrease to negligible PIC01 values in the south. There are of course many other possible explanations (as noted at the start of this section).

Interestingly, these uncertainties regarding the roles of inorganic carbon chemistry and temperature on Southern Ocean coccolithophore distributions contrast with the possible role of macronutrients, in that phosphate and nitrate increase southward across the Southern Ocean (e.g. (Trull et al., 2001b) and were everywhere abundant during our surveys (nitrate $>3 \mu \mathrm{M}$, with phosphate/nitrate close to Redfield expectations; data in the Supplement) and thus would be expected to lead to southward increases in coccolithophore abundances which were not observed. For this reason we suggest that nitrate and phosphate availability is not an obvious driver of the southward decrease in coccolithophore abundances in Southern Ocean HNLC waters (i.e. these nutrients are sufficient everywhere), although these nutrients may be important in determining the success of coccolithophores in oligotrophic waters at the northern edge of the Southern Ocean, given the high half-saturation constant for nitrate uptake observed in some laboratory studies $(\sim 13 \mu \mathrm{M}$; Feng et al., 2016) and the possibility that high-temperature and lownutrient conditions may non-linearly amplify phytoplankton stresses (Thomas et al., 2017).

Importantly, in addition to multivariate environmental control of coccolithophore distributions via their growth rates, there is the possibility of control by resource competition with other autotrophs (presumably mainly for iron) and/or stronger loss terms to grazers in Antarctic than subantarctic waters (Assmy et al., 2013, have suggested preferential grazing as a control on community structure, but we have no data to allow us to evaluate this). These are difficult issues to evaluate, and we provide just one comment. Diatom abundances as estimated from BSi concentrations show a stronger latitudinal relationship to silicon availability than coccolithophores do to carbonate availability (Fig. 7). Diatom abundances drop strongly near the SAF, north of which summertime $\mathrm{Si}(\mathrm{OH})_{4}$ concentrations drop below $1 \mu \mathrm{M}$, i.e. close to the "residual" concentration which it appears diatoms cannot access (Paasche, 1973). Surveys of coccolithophores and diatoms in the SAZ in the South Atlantic and South Indian sectors have previously suggested that coccolithophore distributions may be linked to competition with diatoms (Balch et al., 2016; Smith et al., 2017), and this view is compatible with our observations, although it remains unproven. Further progress in understanding the controls on coccolithophore abundances in the Southern Ocean is clearly needed. At present, temperature, light and competition with diatoms for

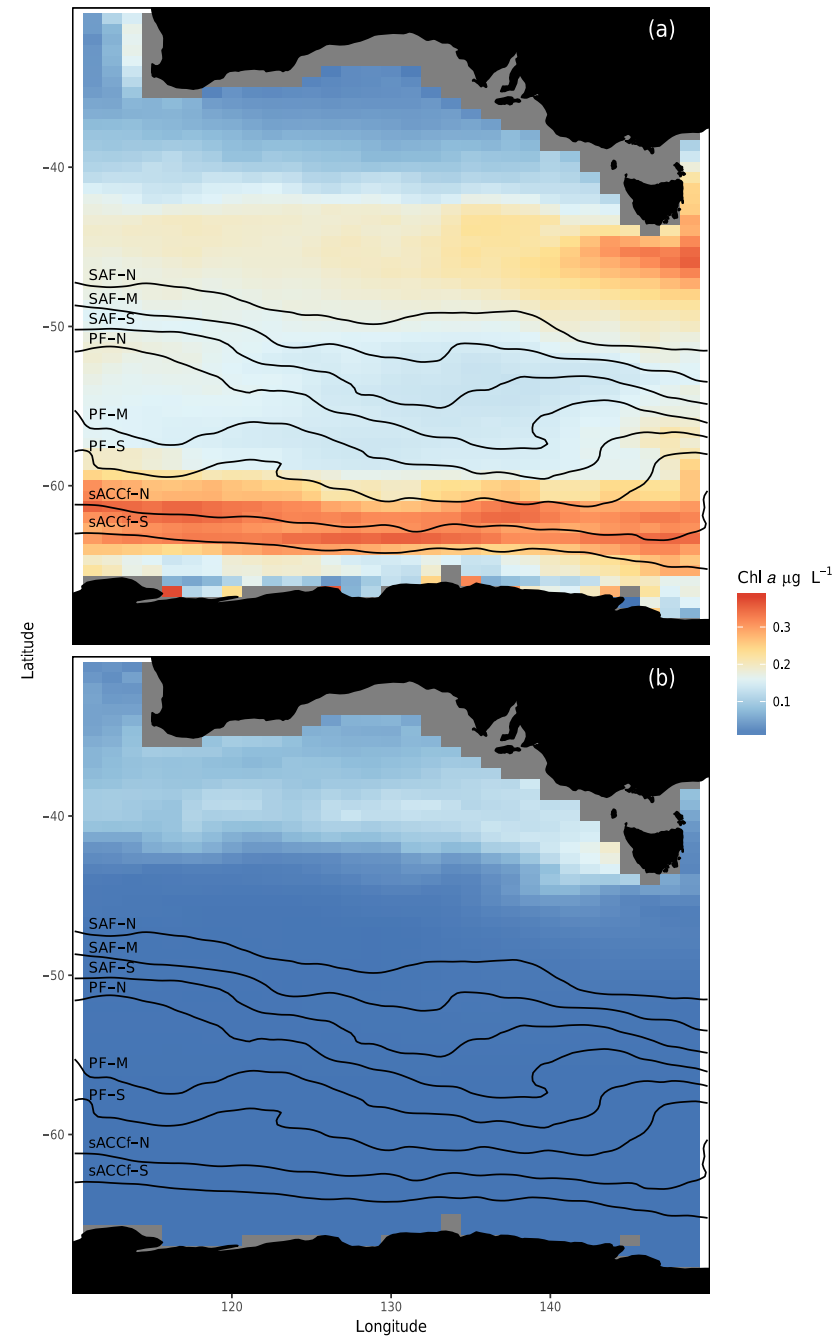

Figure 8. Maps of NASA Ocean Biogeochemical Model results for (a) diatom and (b) coccolithophore distribution. Results are means for productive months (October-March for 2008-2012, 2012 being the last year available online).

iron appear to be the strongest candidates (at least for southward expansion (Charalampopoulou et al., 2016; Gafar et al., 2017; with nitrate a strong influence on the location of the northern oligotrophic boundary: Feng et al., 2016).

\subsection{Comparison to the NASA Ocean Biogeochemical Model}

Many of these ideas about the roles of environmental conditions and ecological competition have been included in models for global coccolithophore distributions (e.g. Gregg and Casey (2007a), Le Quéré et al. (2005)), and we provide a brief comparison to one model - the NASA Ocean Biogeochemical Model (NOBM), for which simulation results are available online (see the Methods section). In brief, the NOBM predicts coccolithophore abundances (in Chl units) 
that are restricted to the far northern reaches of the Southern Ocean (Fig. 8). This is also true for the Dynamic Green Ocean Model (Le Quéré et al., 2005). This contrasts with our PIC results (Figs. 3, 4, 7) and with PIC and coccolithophore cell counts from other sampling efforts, which have found coccolithophore abundances to extend with similar concentrations right across the SAZ and sometimes the PFZ, e.g. during VL6 south of western Australia (Figs. 3 and 7), south of Tasmania (Cubillos et al., 2007), in the Scotia Sea (Holligan et al., 2010), and in the South Atlantic and south Indian oceans, especially in regions of natural iron fertilization (Balch et al., 2016; Smith et al., 2017). In the NOBM, diatoms are also simulated and show (Fig. 8) the expected high abundance in Antarctic waters in the southern third of the Southern Ocean, decreasing northward as in our results (but also show a band of elevated diatom concentrations in the subantarctic, which we did not observe).

Competition for nutrients in the NOBM favours the ability of coccolithophores over diatoms to get by on limited resources (half-saturation constants for nitrate and iron of 0.5 and 0.67 versus 1.0 and $1.0 \mu \mathrm{M}$ ) including light (halfsaturation constant of 56 versus $90 \mu$ mol photons $\mathrm{m}^{-2} \mathrm{~s}^{-1}$ under Southern Ocean low-light conditions). But diatoms are specified to have higher growth rates when all resources are non-limiting (maximum growth rate at $20^{\circ} \mathrm{C} 1.50$ versus 1.13 , both with the same Eppley dependence on temperature). Thus, in the model, diatoms dominate silicon-replete Southern Ocean waters, outcompeting other species for the limiting iron, and only give way to other species when silicon is depleted. Notably these other species then do best when additional $\mathrm{Fe}$ is supplied from either atmospheric sources (in the north where continental dusts are not shielded by ice) or island oases such as Crozet or Kerguelen. This view is compatible with our observations and those carried out in the northern half of the Southern Ocean during the Great Calcite Belt voyages (Balch et al., 2016; Smith et al., 2017). It suggests that the potential expansion of coccolithophores southward might be linked to a decreasing supply of silicon from reduced upwelling of Circumpolar Deep Water in a progressively more stratified global ocean. A cautionary note to this conclusion is provided by the NOBM simulation of significant concentrations of diatoms in the SAZ where silicon is low, which arises from their specified higher maximum growth rate, emphasizing the importance of this parameter, and its temperature dependence in modelling phytoplankton distributions. In specifying this temperature dependence, this model and most others still rely on the global compilation from nearly 50 years ago (Eppley, 1972). Clearly, better understanding of the controls on maximum growth rates and their temperature tolerance for key phytoplankton taxa is needed, first to understand current distributions and then to explore possible future changes.

\section{Conclusions}

Our surveys of PIC concentrations as a proxy for coccolithophores in the Southern Ocean south of Australia suggest the following.

- The concentrations of coccolithophores were much smaller (at least 10-fold) in the open Southern Ocean south of Australia than in Northern Hemisphere oceans.

- Coccolithophores were most abundant in the SAZ and occasionally in the PFZ.

- The contribution of coccolithophores to total phytoplankton biomass (estimated from POC) was small: less than $10 \%$ in subantarctic waters and less than $1 \%$ in Antarctic waters.

- The Great Calcite Belt characterization of SAZ and PFZ waters is overstated south of Australia because both the satellite (SPIC) estimates and our in situ PIC measurements show lower values than in the South Atlantic and south Indian Ocean, where this feature was first suggested.

- The SPIC algorithm provides a good estimate, within a factor of 2-3, of PIC values in subantarctic waters south of Australia but erroneously suggests large agglomerations of PIC in polar waters, where little to none is present south of Australia.

- Our PIC results and ancillary measurements of biogenic silica, particulate organic carbon, dissolved nutrients and inorganic carbon system status may be useful in the testing of models of limiting conditions and ecological competitions that affect coccolithophore distributions. Preliminary considerations suggest that temperature, iron and competition with diatoms may be stronger influences than $\mathrm{pH}$ or calcite saturation state.

Despite the considerable effort required to obtain these survey results, much remains to be done just to define coccolithophore distributions, for example their seasonality, especially when the complexities of differing responses of individual species and strains are considered.

Data availability. All of our data are reported in the Supplement. Modelled coccolithophore distributions were obtained from the data-assimilating general circulation model NASA Ocean Biogeochemical Model (NOBM) (NASA, 2017). The southern repeat data set is available at https://cchdo.ucsd.edu/cruise/09AR20080322, and the I9 data set is available at https://cchdo.ucsd.edu/cruise/ 09AR20120105.

The Supplement related to this article is available online at https://doi.org/10.5194/bg-15-31-2018-supplement. 
Competing interests. The authors declare that they have no conflict of interest.

Special issue statement. This article is part of the special issue "The Ocean in a High- $\mathrm{CO}_{2}$ World IV". It is a result of the 4th International Symposium on the Ocean in a High- $\mathrm{CO}_{2}$ World, Hobart, Australia, 3-6 May 2016.

Acknowledgements. We thank Steve Rintoul (CSIRO Oceans and Atmosphere, Hobart) and Alain Poisson (Université Pierre et Marie Curie, Paris) for allowing sample collection to proceed under the auspices of their science programs on-board Aurora Australis and l'Astrolabe, respectively. ACE CRC staff, students and volunteers carried out on-board sampling, including Erik van Ooijen, Isobel Thomas, Peter Jansen, Stephane Thannassekos and Nick Roden. Nutrient analyses were carried out by the CSIRO hydrochemistry group. Thomas Rodemann at the UTAS Central Sciences Laboratory did the CHN analyses. Funding was provided by the Australian Commonwealth Cooperative Research Centre Program via the ACE CRC. Tim Smit participated in the first voyage in 2008 and described those results in his Utrecht University Master thesis and in a poster presented at the Second Symposium on the Ocean in a High $\mathrm{CO}_{2}$ World, Monoco, 6-9 October 2008. Andrew Lenton (CSIRO) produced the database of absolute mean dynamic heights. Our paper was significantly improved by insightful, constructive reviews from Alex Poulton and Lennart Bach.

Edited by: Kai G. Schulz

Reviewed by: Lennart Bach and Alex Poulton

\section{References}

Anthony, K., Kleypas, J. A., and Gattuso, J. P.: Coral reefs modify their seawater carbon chemistry - implications for impacts of ocean acidification, Global Change Biol., 17, 3655-3666, 2011.

Assmy, P., Smetacek, V., Montresor, M., Klaas, C., Henjes, J., Strass, V. H., Arrieta, J. M., Bathmann, U., Berg, G. M., and Breitbarth, E.: Thick-shelled, grazer-protected diatoms decouple ocean carbon and silicon cycles in the iron-limited Antarctic Circumpolar Current, P. Natl. Acad. Sci. USA, 110, 20633-20638, 2013.

Bach, L. T., Riebesell, U., Gutowska, M., Federwisch, L., and Schulz, K. G.: A unifying concept of coccolithophore sensitivity to changing carbonate chemistry embedded in an ecological framework, Prog. Oceanogr., 135, 125-138, 2015.

Balch, W. M. and Utgoff, P. E.: Potential interactions among ocean acidification, coccolithophores, and the optical properties of seawater, Oceanography, 22, 146-159, 2009.

Balch, W. M., Gordon, H. R., Bowler, B. C., Drapeau, D. T., and Booth, E. S.: Calcium carbonate measurements in the surface global ocean based on Moderate-Resolution Imaging Spectroradiometer data, J. Geophys. Res., 110, C07001, https://doi.org/10.1029/2004JC002560, 2005.

Balch, W. M., Drapeau, D. T., Bowler, B. C., Booth, E. S., Windecker, L. A., and Ashe, A.: Space-time variability of carbon standing stocks and fixation rates in the Gulf of Maine, along the GNATS transect between Portland, ME, USA, and Yarmouth, Nova Scotia, Canada, J. Plankton Res., 30, 119-139, 2008.

Balch, W. M., Drapeau, D. T., Bowler, B. C., Lyczskowski, E., Booth, E. S., and Alley, D.: The contribution of coccolithophores to the optical and inorganic carbon budgets during the Southern Ocean Gas Exchange Experiment: New evidence in support of the "Great Calcite Belt" hypothesis, J. Geophys. Res., 116, C00F06, https://doi.org/10.1029/2011JC006941, 2011.

Balch, W., Drapeau, D., Bowler, B., Lyczkowski, E., Lubelczyk, L., Painter, S., and Poulton, A.: Surface biological, chemical, and optical properties of the Patagonian Shelf coccolithophore bloom, the brightest waters of the Great Calcite Belt, Limnol. Oceanogr., 59, 1715-1732, 2014.

Balch, W. M., Bates, N. R., Lam, P. J., Twining, B. S., Rosengard, S. Z., Bowler, B. C., Drapeau, D. T., Garley, R., Lubelczyk, L. C., and Mitchell, C.: Factors regulating the Great Calcite Belt in the Southern Ocean and its biogeochemical significance, Global Biogeochem. Cycles, 30, 1124-1144, 2016.

Be, A. W. H. and Tolderlund, D.: Distribution and ecology of living planktonic foraminifera in surface waters of the Atlantic and Indian Oceans, in: Micropaleontology of Oceans, edited by: Funnel, B. M. and Riedel, W. R., 105-149, Cambridge University Press, New York, 1971.

Boeckel, B., Baumann, K.-H., Henrich, R., and Kinkel, H.: Coccolith distribution patterns in South Atlantic and Southern Ocean surface sediments in relation to environmental gradients, Deep-Sea Res. Pt. I, 53, 1073-1099, https://doi.org/10.1016/j.dsr.2005.11.006, 2006.

Bowie, A. R., Griffiths, F. B., Dehairs, F., and Trull, T. W.: Oceanography of the subantarctic and Polar Frontal Zones south of Australia during summer: Setting for the SAZ-Sense study, Deep-Sea Res. Pt. II, 58, 2059-2070, https://doi.org/10.1016/j.dsr2.2011.05.033, 2011a.

Bowie, A. R., Trull, T. W., and Dehairs, F.: Estimating the Sensitivity of the Subantarctic Zone to Environmental Change: the SAZ-Sense project, Deep-Sea Res. Pt. II, 58, 2051-2058, $2011 \mathrm{~b}$.

Boyd, P. W. and Trull, T.: Understanding the export of biogenic particles in oceanic waters: Is there consensus?, Prog. Oceanogr., 72, 276-312, https://doi.org/10.1016/j.pocean.2006.10.007, 2007a.

Boyd, P. W. and Trull, T. W.: Understanding the export of marine biogenic particles: is there consensus?, Prog. Oceanogr., 4, 276312, https://doi.org/10.1016/j.pocean.2006.10.007, 2007b.

Brown, C. W. and Yoder, J. A.: Coccolithophore blooms in the global ocean, J. Geophys. Res., 104C, 1541-1558, 1994.

Buitenhuis, E., van der Wal, P., and de Baar, H. J. W.: Blooms of Emiliania huxleyi are sinks of atmospheric carbon dioxide: a field and mesocosm study derived simulation, Global Biogeochem. Cycles, 15, 577-587, 2001.

Cao, L. and Caldeira, K.: Atmospheric $\mathrm{CO}_{2}$ stabilization and ocean acidification, Geophys. Res. Lett., 35, L19609, https://doi.org/10.1029/2008GL035072, 2008.

Charalampopoulou, A., Poulton, A. J., Bakker, D. C. E., Lucas, M. I., Stinchcombe, M. C., and Tyrrell, T.: Environmental drivers of coccolithophore abundance and calcification across Drake Passage (Southern Ocean), Biogeosciences, 13, 59175935, https://doi.org/10.5194/bg-13-5917-2016, 2016.

Cubillos, J. C., Wright, S. W., Nash, G., Salas, M. F. D., Griffiths, B., Tilbrook, B., Poisson, A., and Hallegraeff, G. M.: Calcification morphotypes of the coccolithophorid Emiliania hux- 
leyi in the Southern Ocean: changes in 2001 to 2006 compared to historical data, Mar. Ecol. Prog. Ser., 348, 47-54, https://doi.org/10.3354/meps07058, 2007.

Dickson, A. G., Sabine, C. L., and Christian, J. R.: Guide to Best Practices for Ocean $\mathrm{CO}_{2}$ Measurements, Rep., Sidney, British Columbia, 2007.

Doubleday, A. J. and Hopcroft, R. R.: Interannual patterns during spring and late summer of larvaceans and pteropods in the coastal Gulf of Alaska, and their relationship to pink salmon survival, J. Plankton Res., 37, 134-150, https://doi.org/10.1093/plankt/fbu092, 2015.

Eppley, R. W.: Temperature and phytoplankton growth in the sea, Fish. B., 70, 1063-1085, 1972.

Eriksen, R.: A practical manual for the determination of salinity, dissolved oxygen, and nutrients in seawater, Rep. 11, 83 p., Hobart, Tasmania, Australia, 1997.

Eynaud, F., Giraudeau, J., Pichon, J. J., and Pudsey, C. J.: Seasurface distribution of coccolithophores, diatoms, silicoflagellates and dinoflagellates in the South Atlantic Ocean during the late austral summer 1995, Deep-Sea Res. Pt. I, 46, 451-482, https://doi.org/10.1016/S0967-0637(98)00079-X, 1999.

Feng, Y., Roleda, M. Y., Armstrong, E., Boyd, P. W., and Hurd, C. L.: Environmental controls on the growth, photosynthetic and calcification rates of a Southern Hemisphere strain of the coccolithophore Emiliania huxleyi, Limnol. Oceanogr., 62, 519-540, https://doi.org/10.1002/lno.10442, 2016.

Findlay, C. S. and Giraudeau, J.: Extant calcareous nannoplankton in the Australian Sector of the Southern Ocean (austral summers 1994 and 1995), Mar. Micropaleontol., 40, 417-439, https://doi.org/10.1016/S0377-8398(00)00046-3, 2000.

Gafar, N. A., Eyre, B. D., and Shulz, K. G.: A conceptual model for projecting coccolithophorid growth, calcification, and photosynthetic carbon fixation rates in response to global change (carbonate chemistry speciation, temperature, and light) based on Gephyrocapsa oceanica, Front. Mar. Sci., in review, 2017.

Gattuso, J.-P., Frankignoulle, M., Bourge, I., Romaine, S., and Buddemeier, R.: Effect of calcium carbonate saturation of seawater on coral calcification, Global Planet. Change, 18, 37-46, 1998.

Gravalosa, J. M., Flores, J.-A., Sierro, F. J., and Gersonde, R.: Sea surface distribution of coccolithophores in the eastern Pacific sector of the Southern Ocean (Bellingshausen and Amundsen Seas) during the late austral summer of 2001, Mar. Micropaleontol., 69, 16-25, https://doi.org/10.1016/j.marmicro.2007.11.006, 2008.

Gregg, W. W. and Casey, N. W.: Modeling coccolithophores in the global oceans, Deep-Sea Res. Pt. II, 54, 447-477, 2007a.

Gregg, W. W. and Casey, N. W.: Modeling coccolithophores in the global oceans, Deep-Sea Res. Pt. II, 54, 447-477, https://doi.org/10.1016/j.dsr2.2006.12.007, 2007b.

Grenier, M., Della Penna, A., and Trull, T. W.: Autonomous profiling float observations of the high-biomass plume downstream of the Kerguelen Plateau in the Southern Ocean, Biogeosciences, 12, 2707-2735, https://doi.org/10.5194/bg-12-2707-2015, 2015.

Haëntjens, N., Boss, E., and Talley, L. D.: Revisiting Ocean Color algorithms for chlorophyll a and particulate organic carbon in the Southern Ocean using biogeochemical floats, J. Geophys. Res.-Oceans, 122, 6583-6593, https://doi.org/10.1002/2017JC012844, 2017.
Holligan, P., Charalampopoulou, A., and Hutson, R.: Seasonal distributions of the coccolithophore, Emiliania huxleyi, and of particulate inorganic carbon in surface waters of the Scotia Sea, J. Mar. Syst., 82, 195-205, 2010.

Hood, R. R., Laws, E. A., Armstrong, R. A., Bates, N. R., Brown, C. W., Carlson, C. A., Chai, F., Doney, S. C., Falkowski, P. G., and Feely, R. A.: Pelagic functional group modeling: Progress, challenges and prospects, Deep-Sea Res. Pt. II, 53, 459-512, 2006.

Johnson, R., Strutton, P. G., Wright, S. W., McMinn, A., and Meiners, K. M.: Three Improved Satellite Chlorophyll Algorithms for the Southern Ocean, J. Geophys. Res.-Oceans, 118, 3694-3703, https://doi.org/10.1002/jgrc.20270, 2013.

Kimball Jr., J. and Ferguson Wood, E.: A simple centrifuge for phytoplankton studies, B. Mar. Sci., 14, 539-544, 1964.

King, A. L. and Howard, W. R.: Planktonic foraminiferal flux seasonality in Subantarctic sediment traps: A test for paleoclimate reconstructions, Paleooceanography, 18, 1019, https://doi.org/10.1029/2002PA000839, 2003.

King, P., Kennedy, H., Newton, P. P., Jickells, T. D., Brand, T., Calvert, S., Cauwet, G., Etcheber, H., Head, B., and Khripounoff, A.: Analysis of total and organic carbon and total nitrogen in settling oceanic particles and a marine sediment: an interlaboratory comparison, Mar. Chem., 60, 203-216, 1998.

Klaas, C. and Archer, D. E.: Association of sinking organic matter with various types of mineral ballast in the deep sea: Implications for the rain ratio, Global Biogeochem. Cycles, 16, 1116, https://doi.org/10.1029/2001GB001765, 2002.

Langdon, C., Takahashi, T., Sweeney, C., Chipman, D. W., and Goddard, J.: Effect of calcium carbonate saturation state on the calcification rate on an experimental coral reef, Global Biogeochem. Cycles, 14, 639-654, 2000.

Le Quéré, C., Harrison, S. P., Colin Prentice, I., Buitenhuis, E. T., Aumont, O., Bopp, L., Claustre, H., Cotrim Da Cunha, L., Geider, R., and Giraud, X.: Ecosystem dynamics based on plankton functional types for global ocean biogeochemistry models, Global Change Biol., 11, 2016-2040, 2005.

Mackinder, L., Wheeler, G., Schroeder, D., Riebesell, U., and Brownlee, C.: Molecular mechanisms underlying calcification in coccolithophores, Geomicrobiol. J., 27, 585-595, 2010.

McNeil, B. I. and Matear, R. J.: Southern Ocean acidification: A tipping point at 450-ppm atmospheric $\mathrm{CO}_{2}$, P. Natl. Acad. Sci. USA, 105, 18860-18864, https://doi.org/10.1073/pnas.0806318105, 2008.

Merico, A., Tyrrell, T., Lessard, E. J., Oguz, T., Stabeno, P. J., Zeeman, S. I., and Whitledge, T. E.: Modelling phytoplankton succession on the Bering Sea shelf: role of climate influences and trophic interactions in generating Emiliania huxleyi blooms 1997-2000, Deep-Sea Res. Pt. I, 51, 1803-1826, https://doi.org/10.1016/j.dsr.2004.07.003, 2004.

Mohan, R., Mergulhao, L. P., Guptha, M. V. S., Rajakumar, A., Thamban, M., AnilKumar, N., Sudhakar, M., and Ravindra, R.: Ecology of coccolithophores in the Indian sector of the Southern Ocean, Mar. Micropaleontol., 67, 30-45, https://doi.org/10.1016/j.marmicro.2007.08.005, 2008.

Moore, J. K. and Abbott, M. R.: Surface chlorophyll concentrations in relation to the Antarctic Polar Front: seasonal and spatial patterns from satellite observations, J. Mar. Syst., 37, 69-86, 2002.

Moore, J. K., Abbot, M. R., Richman, J. G., Smith, W. O., Cowles, T. J., Coale, K. H., Gardner, W. D., and Barber, R. T.: SeaWiFS 
satellite ocean color data from the Southern Ocean, Gephys. Res. Lett., 26, 1465-1468, https://doi.org/10.1029/1999GL900242, 1999.

Moore, J. K., Doney, S. C., Kleypas, J. A., Glover, D. M., and Fung, I. Y.: An intermediate complexity marine ecosystem model for the global domain, Deep-Sea Res. Pt. II, 49, 403-462, 2002.

Morel, A. and Maritorena, S.: Bio-optical properties of oceanic waters- A reappraisal, J. Geophys. Res., 106, 7163-7180, 2001.

Mortyn, P. G. and Charles, C. D.: Planktonic foraminiferal depth habitat and $\delta^{18} \mathrm{O}$ calibrations: Plankton tow results from the Atlantic sector of the Southern Ocean, Paleoceanography, 18, 1037, https://doi.org/10.1029/2001PA000637, 2003.

Moy, A. D., Howard, W., Bray, S. G., and Trull, T.: Reduced calcification in modern Southern Ocean planktonic foraminifera, Nature Geosci., 2, 276-280, https://doi.org/10.1038/NGEO460, 2009.

Muller, M. N., Trull, T., and Hallegraeff, G. M.: Differing responses of three Southern Ocean Emiliania huxleyi ecotypes to changing seawater carbonate chemistry, Mar. Ecol. Prog. Ser., 531, 81-90, https://doi.org/10.3354/meps11309, 2015.

Müller, M. N., Trull, T. W., and Hallegraeff, G. M.: Independence of nutrient limitation and carbon dioxide impacts on the Southern Ocean coccolithophore Emiliania huxleyi, The ISME Journal, 11, 1777-1787, https://doi.org/10.1038/ismej.2017.53, 2017.

NASA: NASA Ocean Biogeochemical Model, available at: https://giovanni.gsfc.nasa.gov/giovanni/\#service= TmAvMp\&starttime $=\&$ endtime $=\&$ data $=$ NOBM_MON_ R2014_coc\&variableFacets=dataFieldDiscipline $\% 3$ AOcean $\%$ 20Biology\%3BdataFieldMeasurement\%3APhytoplankton\%3B, last access: 26 May 2017.

NASA Goddard Space Flight Center, Ocean Ecology Laboratory, Ocean Biology Processing Group: Moderate-resolution Imaging Spectroradiometer (MODIS) Aqua Chlorophyll Data, 2014 Reprocessing, NASA OB.DAAC, Greenbelt, MD, USA, https://doi.org/10.5067/AQUA/MODIS/L3M/CHL/2014, 2014a.

NASA Goddard Space Flight Center, Ocean Ecology Laboratory, Ocean Biology Processing Group: Moderate-resolution Imaging Spectroradiometer (MODIS) Aqua Particulate Inorganic Carbon Data, 2014 Reprocessing. NASA OB.DAAC, Greenbelt, MD, USA, https://doi.org/10.5067/AQUA/MODIS/L3M/PIC/2014, 2014b.

Nelson, D. M., Brzezinski, M. A., Sigmon, D. E., and Frank, V. M.: A seasonal progression of Si limitation in the Pacific sector of the Southern Ocean, Deep-Sea Res. Pt. II, 48, 3973-3995, 2001.

Norberg, J.: Biodiversity and ecosystem functioning: a complex adaptive systems approach, Limnol. Oceanogr., 49, 1269-1277, 2004.

Olbers, D. J., Gouretski, V., and Schroter, G. S. J.: Hydrographic Atlas of the Southern Ocean, 99 p., Alfred Wegener Institute for Polar and Marine Research, Bremerhaven, 1992.

Orr, J. C., Fabry, V. J., Aumont, O., Bopp, L., Doney, S. C., Feely, R. A., Gnanadesikan, A., Gruber, N., Ishida, A., Joos, F., Key, R. M., Lindsay, K., Maier-Reimer, E., Matear, R., Monfray, P., Mouchet, A., Najjar, R. G., Plattner, G.-K., Rodgers, K. B., Sabine, C. L., Sarmiento, J. L., Schlitzer, R., Slater, R. D., Totterdell, I. J., Weirig, M-F., Yamanaka, Y., and Yool, A.: Anthropogenic ocean acidification over the twenty-first century and its impact on calcifying organisms, Nature, 437, 681-686, https://doi.org/10.1038/nature04095, 2005.
Paasche, E.: Silicon and the ecology of marine plankton diatoms. I. Thalassiosira pseudonana (Cyclotella nana) grown in a chemostat with silicate as limiting nutrient, Mar. Biol., 19, 117-126, 1973.

Parslow, J., Boyd, P., Rintoul, S. R., and Griffiths, F. B.: A persistent sub-surface chlorophyll maximum in the Polar Frontal Zone south of Australia: seasonal progression and implications for phytoplankton-light-nutrient interactions, J. Geophys. Res., 106, 31543-31557, 2001.

Pörtner, H. O., Langenbuch, M., and Michaelidis, B.: Synergistic effects of temperature extremes, hypoxia, and increases in $\mathrm{CO}_{2}$ on marine animals: From Earth history to global change, J. Geophys. Res.-Oceans, 110, C09S10, https://doi.org/10.1029/2004JC002561, 2005.

Poulton, A. J., Young, J. R., Bates, N. R., and Balch, W. M.: Biometry of detached Emiliania huxleyi coccoliths along the Patagonian Shelf, Mar. Ecol. Prog. Ser., 443, 1-17, 2011.

Poulton, A. J., Painter, S. C., Young, J. R., Bates, N. R., Bowler, B., Drapeau, D., Lyczsckowski, E., and Balch, W. M.: The 2008 Emiliania huxleyi bloom along the Patagonian Shelf: Ecology, biogeochemistry, and cellular calcification, Global Biogeochem. Cycles, 27, 1023-1033, 2013.

Pujol, M.-I., Faugère, Y., Taburet, G., Dupuy, S., Pelloquin, C., Ablain, M., and Picot, N.: DUACS DT2014: the new multimission altimeter data set reprocessed over 20 years, Ocean Sci., 12, 1067-1090, https://doi.org/10.5194/os-12-1067-2016, 2016.

Ragueneau, O., Dittert, N., Pondaven, P., Treguer, P., and Corrin, L.: Si/C decoupling in the world ocean: is the Southern Ocean different?, Deep-Sea Res. Pt. II, 49, 3127-3154, 2002.

Ragueneau, O., Schultes, S., Bidle, K., Claquin, P., and Moriceau, $\mathrm{B} . \mathrm{Si}$ and $\mathrm{C}$ interactions in the world ocean: Importance of ecological processes and implications for the role of diatoms in the biological pump, Global Biogeochem. Cycles, 20, GB4S02, https://doi.org/10.1029/2006GB002688, 2006.

Ridgwell, A., Schmidt, D. N., Turley, C., Brownlee, C., Maldonado, M. T., Tortell, P., and Young, J. R.: From laboratory manipulations to Earth system models: scaling calcification impacts of ocean acidification, Biogeosciences, 6, 2611-2623, https://doi.org/10.5194/bg-6-2611-2009, 2009.

Rintoul, S. R. and Trull, T.: Seasonal evolution of the mixed layer in the Subantarctic Zone south of Australia, J. Geophys. Res., 106, 31447-31462, https://doi.org/10.1029/2000JC000329, 2001.

Rivero-Calle, S., Gnanadesikan, A., Del Castillo, C. E., Balch, W. M., and Guikema, S. D.: Multidecadal increase in North Atlantic coccolithophores and the potential role of rising $\mathrm{CO}_{2}$, Science, 350, 1533-1537, 2015.

Roberts, D., Howard, W. R., Roberts, J. L., Bray, S. G., Moy, A. D., Trull, T., and Hopcroft, R. R.: Diverse trends in shell weight of three Southern Ocean pteropod taxa collected with Polar Frontal Zone sediment traps from 1997 to 2007, Polar Biol., 37, 14451458, https://doi.org/10.1007/s00300-014-1534-6, 2014.

Roden, N. P., Tilbrook, B., Trull, T. W., Virtue, P., and Williams, G. D.: Carbon cycling dynamics in the seasonal sea-ice zone of East Antarctica, J. Geophys. Res.-Oceans, 121, 8749-8769, https://doi.org/10.1002/2016JC012008, 2016.

Rost, B. and Riebesell, U.: Coccolithophores and the biological pump: responses to environmental changes, in: Coccolithophores, edited, 99-125, Springer, 2004. 
Salter, I., Schiebel, R., Ziveri, P., Movellan, A., Lampitt, R., and Wolff, G. A.: Carbonate counter pump stimulated by natural iron fertilization in the Polar Frontal Zone, Nature Geosci., 7, 885889, https://doi.org/10.1038/ngeo2285, 2014.

Schiebel, R.: Planktic foraminiferal sedimentation and the marine calcite budget, Global Biogeochem. Cycles, 16, 1065, https://doi.org/10.1029/2001GB001459, 2002.

Schlüter, L., Lohbeck, K. T., Gutowska, M. A., Gröger, J. P., Riebesell, U., and Reusch, T. B.: Adaptation of a globally important coccolithophore to ocean warming and acidification, Nature Clim. Change, 4, 1024-1030, 2014.

Schulz, K. G., Rost, B., Burkhardt, S., Riebesell, U., Thoms, S., and Wolf-Gladrow, D.: The effect of iron availability on the regulation of inorganic carbon acquisition in the coccolithophore Emiliania huxleyi and the significance of cellular compartmentation for stable carbon isotope fractionation, Geochim. Cosmochim. Ac., 71, 5301-5312, 2007.

Sett, S., Bach, L. T., Schulz, K. G., Koch-Klavsen, S., Lebrato, M., and Riebesell, U.: Temperature modulates coccolithophorid sensitivity of growth, photosynthesis and calcification to increasing seawater $p \mathrm{CO}_{2}$, PLoS One, 9, e88308, https://doi.org/10.1371/journal.pone.0088308, 2014.

Shadwick, E. H., Trull, T., Thomas, H., and Gibson, J. A. E.: Vulnerability of Polar Oceans to Anthropogenic Acidification: Comparison of Arctic and Antarctic Seasonal Cycles, Scientific Reports, 3, 1-7, https://doi.org/10.1038/srep02339, 2013.

Shadwick, E. H., Tilbook, B., Cassar, N., Trull, T. W., and Rintoul, S. R.: Summertime physical and biological controls on $\mathrm{O}_{2}$ and $\mathrm{CO}_{2}$ in the Australian Sector of the Southern Ocean, J. Mar. Syst., 147, 21-28, https://doi.org/10.1016/j.jmarsys.2013.12.008, 2015.

Silverman, J., Lazar, B., and Erez, J.: Effect of aragonite saturation, temperature, and nutrients on the community calcification rate of a coral reef, J. Geophys. Res.-Oceans, 112, C05004, https://doi.org/10.1029/2006JC003770, 2007.

Smith, H. E. K., Poulton, A. J., Garley, R., Hopkins, J., Lubelczyk, L. C., Drapeau, D. T., Rauschenberg, S., Twining, B. S., Bates, N. R., and Balch, W. M.: The influence of environmental variability on the biogeography of coccolithophores and diatoms in the Great Calcite Belt, Biogeosciences, 14, 4905-4925, https://doi.org/10.5194/bg-14-4905-2017, 2017.

Sokolov, S. and Rintoul, S. R.: Structure of Southern Ocean fronts at 140E, J. Mar. Syst., 37, 151-184, 2002.

Sokolov, S. and Rintoul, S. R.: Multiple jets of the Antarctic Circumpolar Current south of Australia, J. Phys. Oceanogr., 37, 1394-1412, https://doi.org/10.1175/JPO3111.1, 2007a.
Sokolov, S. and Rintoul, S. R.: On the relationship between fronts of the Antarctic Circumpolar Current and surface chlorophyll concentrations in the Southern Ocean, J. Geophys. Res.-Oceans, 112, C07030, https://doi.org/10.1029/2006JC004072, 2007b.

Takahashi, K. and Okada, H.: Environmental control on the biogeography of modern coccolithophores in the southeastern Indian Ocean offshore of Western Australia, Mar. Micropaleontol., 39, 73-86, https://doi.org/10.1016/S0377-8398(00)00015-3, 2000.

Takeda, S.: Influence of iron availability on nutrient consumption ratio of diatoms in oceanic waters, Nature, 393, 774-777, 1998.

Thomas, M. K., Aranguren-Gassis, M., Kremer, C. T., Gould, M. R., Anderson, K., Klausmeier, C. A., and Litchman, E.: Temperature-nutrient interactions exacerbate sensitivity to warming in phytoplankton, Global Change Biol., 23, 3269-3280, https://doi.org/10.1111/gcb.13641, 2017.

Trull, T., Bray, S. G., Manganini, S. J., Honjo, S., and Francois, R.: Moored sediment trap measurements of carbon export in the Subantarctic and Polar Frontal Zones of the Southern Ocean, south of Australia, J. Geophys. Res., 106, 31489-31509, https://doi.org/10.1029/2000JC000308, 2001a.

Trull, T., Rintoul, S. R., Hadfield, M., and Abraham, E. R.: Circulation and seasonal evolution of polar waters south of Australia: Implications for iron fertilization of the Southern Ocean, DeepSea Res. Pt. II, 48, 2439-2466, https://doi.org/10.1016/s09670645(01)00003-0, 2001b.

Van Heuven, S., Pierrot, D., Rae, J., Lewis, E., and Wallace, D.: MATLAB program developed for $\mathrm{CO}_{2}$ system calculations, ORNL/CDIAC-105b, Carbon Dioxide Inf, Anal. Cent., Oak Ridge Natl. Lab., US DOE, Oak Ridge, Tenn., 2011.

Wright, S. W. and van den Enden, R. L.: Phytoplankton community structure and stocks in the East Antarctic marginal ice zone (BROKE survey, Jan.-Mar.1996) determined by CHEMTAX analysis of HPLC pigment signatures, Deep-Sea Res. Pt. II, 47, 2363-2400, 2000

Wright, S. W., Thomas, D. P., Marchant, H. J., Higgins, H. W., Mackey, M. D., and Mackey, D. J.: Analysis of phytoplankton of the Australian sector of the Southern Ocean: comparisons of microscopy and size frequency data with interpretations of pigment HPLC data using the 'CHEMTAX' matrix factorisation program, Mar. Ecol. Prog. Ser., 144, 285-298, 1996.

Zhang, Y., Bach, L. T., Schulz, K. G., and Riebesell, U.: The modulating effect of light intensity on the response of the coccolithophore Gephyrocapsa oceanica to ocean acidification, Limnol. Oceanogr., 60, 2145-2157, 2015. 